OPEN ACCESS

Edited by:

Debarati Paul,

Amity University, India

Reviewed by:

Alok Patel,

Luleå University of Technology,

Sweden

Ameeta RaviKumar,

Savitribai Phule Pune University, India

${ }^{*}$ Correspondence:

Jesus Simal-Gandara

jsimal@uvigo.es

S. P. Jeevan Kumar

jeevanicar@gmail.com

Specialty section:

This article was submitted to

Microbiotechnology,

a section of the journal

Frontiers in Microbiology

Received: 25 January 2021

Accepted: 30 June 2021

Published: 12 August 2021

Citation:

Chintagunta $A D$, Zuccaro $G$ Kumar M, Kumar SPJ, Garlapati VK,

Postemsky PD, Kumar NSS, Chandel AK and Simal-Gandara J (2021) Biodiesel Production From

Lignocellulosic Biomass Using Oleaginous Microbes: Prospects for Integrated Biofuel Production.

Front. Microbiol. 12:658284. doi: 10.3389/fmicb.2021.658284

\section{Biodiesel Production From} Lignocellulosic Biomass Using Oleaginous Microbes: Prospects for Integrated Biofuel Production

\author{
Anjani Devi Chintagunta ${ }^{1}$, Gaetano Zuccaro 2,3 , Mahesh Kumar', S. P. Jeevan Kumar,6, \\ Vijay Kumar Garlapati ${ }^{7}$, Pablo D. Postemsky ${ }^{8}$, N. S. Sampath Kumar ${ }^{1}$, Anuj K. Chande/ ${ }^{9}$ \\ and Jesus Simal-Gandara ${ }^{10 *}$ \\ ${ }^{1}$ Department of Biotechnology, Vignan's Foundation for Science, Technology and Research, Guntur, India, ${ }^{2}$ Department \\ of Chemical, Materials and Production Engineering, Università degli Studi di Napoli Federico II, Naples, Italy, ${ }^{3}$ LBE, INRAE, \\ Université de Montpellier, Narbonne, France, ${ }^{4}$ College of Agriculture, Central Agricultural University, Imphal, India, \\ ${ }^{5}$ ICAR-Indian Institute of Seed Science, Mau, India, ${ }^{6}$ ICAR-Directorate of Floricultural Research, Pune, India, ${ }^{7}$ Department \\ of Biotechnology and Bioinformatics, Jaypee University of Information Technology, Waknaghat, India, ${ }^{8}$ Laboratory \\ of Biotechnology of Edible and Medicinal Mushrooms, Centro de Recursos Naturales Renovables de la Zona Semiárida \\ (CERZOS-UNS/CONICET), Buenos Aires, Argentina, ${ }^{9}$ Department of Biotechnology, Engineering School of Lorena (EEL), \\ University of São Paulo (USP), Lorena, Brazil, ${ }^{10}$ Nutrition and Bromatology Group, Department of Analytical and Food \\ Chemistry, Faculty of Food Science and Technology, University of Vigo, Ourense, Spain
}

Biodiesel is an eco-friendly, renewable, and potential liquid biofuel mitigating greenhouse gas emissions. Biodiesel has been produced initially from vegetable oils, non-edible oils, and waste oils. However, these feedstocks have several disadvantages such as requirement of land and labor and remain expensive. Similarly, in reference to waste oils, the feedstock content is succinct in supply and unable to meet the demand. Recent studies demonstrated utilization of lignocellulosic substrates for biodiesel production using oleaginous microorganisms. These microbes accumulate higher lipid content under stress conditions, whose lipid composition is similar to vegetable oils. In this paper, feedstocks used for biodiesel production such as vegetable oils, nonedible oils, oleaginous microalgae, fungi, yeast, and bacteria have been illustrated. Thereafter, steps enumerated in biodiesel production from lignocellulosic substrates through pretreatment, saccharification and oleaginous microbe-mediated fermentation, lipid extraction, transesterification, and purification of biodiesel are discussed. Besides, the importance of metabolic engineering in ensuring biofuels and biorefinery and a brief note on integration of liquid biofuels have been included that have significant importance in terms of circular economy aspects.

Keywords: biodiesel, bioethanol, greenhouse gas, lignocellulosic materials, liquid fuels

\section{INTRODUCTION}

Biodiesel is one of the prospective renewable fuels produced from different plant oils, animal fats, waste oils, and microbial lipids (Banerjee et al., 2019a; Kumar et al., 2020c). The exorbitant cost of vegetable and non-edible oils, requirement of acreage, and lower yield of oil have forfeited the purpose of using these feedstocks for biodiesel production (Nathan et al., 2019). In general, these feedstocks incur $75 \%$ of the overall production cost of biodiesel production (Subramanian et al., 2010). The development of cost-effective feedstocks coupled with judicious utilization 
of waste substrates could be a viable option to reduce the cost of the process. In addition, encouraging circular economy process is gaining significant interest to reduce the wastage of resources (Kumar and Banerjee, 2019).

Oleaginous microorganisms (OMs) are capable of utilizing inexpensive feedstocks [agro-residues, lignocellulosic substrates (LCSs)] and waste substrates for higher lipid accumulation (Kumar et al., 2020d). Besides, employing OMs could realize the potential of circular economy and development of costeffective processes. For instance, crude glycerol, a by-product of the biodiesel industry, can be supplemented as a carbon source for lipid accumulation (Kumar et al., 2020e). Thereafter, these lipids can be converted to fatty acid methyl esters (FAMEs) and glycerol that again can be recycled. Envisaging this process could realize the viability of the process and hence cost-effective biodiesel production using agro-residues, glycerol, and other waste substrates (Chandel et al., 2020).

Production of OMs is easy to scale up, does not require land and acreage, and results in higher lipid accumulation within shorter incubation times with desirable lipid composition. In case of oleaginous microalgae, they can assimilate atmospheric carbon dioxide into lipid synthesis that ultimately helps in carbon sequestration (Kumar et al., 2017a). Tapping the potential of OMs and lignocellulosic biomass (LCB), this paper is mainly aimed to disseminate the usage of LCS for biodiesel production using OMs. Besides, an integration biofuel production such as bioethanol and biodiesel can also be produced through circular economy process.

\section{CONVENTIONAL FEEDSTOCKS USED FOR BIODIESEL PRODUCTION}

Feedstocks' price has been identified as the most significant factor affecting the overall economic feasibility of biodiesel market (Zhang et al., 2003; Dorado et al., 2006). Approximately, feedstock cost incurs $70-75 \%$ of the total biodiesel production cost (Haas et al., 2006). Thus, to provide viable biodiesel, the raw material cost must be considered a key parameter (Dorado, 2008). For an efficient biodiesel production process, usage of low-cost feedstock, low production costs, and large production scale should be considered as an important requisite. The most common feedstocks used for biodiesel production are vegetable oils derived from edible plants, but the ethical awareness about the use of food as fuel and their high cost have encouraged research efforts to search for low-cost non-food feedstocks.

Criteria for effective utilization of non-food feedstocks should supply raw material for an entire year, value-added products for biochemicals, favorable fatty acid composition, low agricultural inputs (water, fertilizer, pesticides), high oil content, and adaptability to local growing conditions (rainfall, soil type, latitude, etc.) (Patel et al., 2017). Feedstock-derived biodiesel meeting at least the majority of the above criteria represents the most effective alternative to petrodiesel. Since last several years, various feedstocks have been explored for biodiesel production, which can be categorized into four groups: vegetable oil (edible and non-edible), waste or recycled oil, animal fat, and OMs (Kumar et al., 2019).

\section{Vegetable Oil (Edible and Non-edible)}

Vegetable oil as biodiesel feedstock has a number of advantages such as transportability, easy availability, sustainability, high combustion ability, minor sulfur content, lesser aromatic content, and eco-friendly nature (Demirbas et al., 2016), while the major drawbacks include highly viscous nature and unsaturated hydrocarbon chain reactivity (Demirbas, 2009a,b). Vegetable oil includes edible and non-edible oil. Edible vegetable oil is the first and main feedstock for the production of biodiesel. Edible oil-based biodiesel shares in excess of 95\% world biodiesel production (Sajjadi et al., 2016). The wide utilization of edible oils as biodiesel feedstock is due to their availability, easy processing, and biodiesel quality obtained from them.

The most widely used edible vegetable oil feedstocks for global biodiesel production are rapeseed oil used in Europe and Canada, sunflower oil used in Europe, palm oil in Southeast Asia, and soybean oil in the United States (Demirbas et al., 2016). The other edible oils that were explored for biodiesel production are corn, cottonseed, coconut, peanut, linseed, sesame, almond, etc. However, it is improbable for these to be used for commercial biodiesel production because of their high production and trading price. Global biodiesel production has mostly derived from rapeseed oil and sunflower oil, which contribute 84 and $13 \%$ of the total production, respectively (Atabani et al., 2012).

Palm oil contributes $1 \%$, while others including soybeans account for $2 \%$ of the global biodiesel production (Atabani et al., 2012). However, edible oils cannot be served as a long-standing choice for potential feedstock because of issues associated with it, out of which significant increase of their price and food vs. fuel crisis are major constraints. There are also environmental concerns associated with the production of edible oil-based biodiesel to fulfill the market demand. There is a need to enhance feedstock production that leads to deforestation, consumption of ample agricultural lands, damage of vital soil resources, among others (Sajjadi et al., 2016). Non-edible vegetable oil has been found as a potential alternative to edible oil for biodiesel production. They have certain advantages over edible vegetable oil feedstock, as they can grow on wasteland, they have a low cost of growing, and there is no food vs. fuel issue. In the last few years, biodiesel production from various non-edible oil sources has been extensively studied (Jena et al., 2010; Sharma and Singh, 2010; Wang et al., 2011).

Many non-edible oil-producing plants were investigated for biodiesel feedstock, which includes Jatropha curcas (jatropha), Pongamia pinnata (karanja), Hevea brasiliensis (rubber), Madhuca indica (mahua), Ricinus communis (castor), Azadirachta indica (neem), Nicotiana tabacum (tobacco), Gossypium hirsutum (cotton seed), Simmondsia chinensis (jojoba), Moringa oleifera (moringa), Mesua ferrea (Nahor), Simarouba glauca (Simarouba), Sapindus mukorossi (soap nut), and Schleichera oleosa (kusum) (Singh et al., 2020). Non-edible vegetable oil is a better alternative but has some constraints in the path to be suitable for biodiesel feedstock such as long growing period, requirement of ample land for sufficient production, and variation in lipid quality upon changing the plant species, climate, season, and geography (Kumar et al., 2020a). 


\section{Waste or Recycled Oil}

Any oils that are unsuitable for its original purpose after being used owing to the presence of impurities or loss of original properties are termed waste oil. It could be a good feedstock alternative for biodiesel production, as it is much cheaper compared to vegetable oil. In the global scenario, there is generation of a huge quantity of waste oils from household and industrial sectors. A study reported approximately 7,00,000 to $10,00,000$ tons/year generation of waste cooking oil in the EU (Supple et al., 2002). In Canada, yellow grease [waste cooking oil with free fatty acid (FFA) content less than 15\%] generation was reported about 1,20,000 tons/year (Zhang et al., 2003).

Disposal of large amounts of waste oil is a serious environmental problem in many countries. Utilization of waste oil for biodiesel production has potential to solve this problem. However, the presence of many impurities such as FFAs, polymer, and many other compounds in the waste oils makes their conversion to biodiesel a complex process. Moreover, logistics and collection infrastructure are not well developed and hence could be a hurdle due to scattered sources (Sajjadi et al., 2016). Extensive literature has been published on the utilization of waste oil as biodiesel feedstock (Yaakob et al., 2013; Hajjaria et al., 2017; Fonseca et al., 2019; Talavari et al., 2020).

\section{Animal Fat}

Similar to waste oil, animal fat is a cheaper source for biodiesel production and has an environmental advantage as using the waste. In the United States, animal fats account for one-third of the produced fats and oils (Sajjadi et al., 2016). The production cost of biodiesel from refined animal fats was estimated to be 0.4-0.5 USD per liter, which is lower compared to the cost of vegetable oil transesterification (around 0.6-0.8 USD per liter) (Balat, 2011). Generally, major animal fats include tallow, lard, poultry fat, fish processing industry-generated fat, and fat from the leather industries.

Industrial-scale biodiesel production using some of the animal fat feedstocks has already been reported (Schörken and Kempers, 2009). The animal fat-derived biodiesel has higher caloric value, cetane number, and oxidation stability (Ramírez-Verduzco et al., 2012; Adewale et al., 2015), but due to the high amount of FFAs and saturated fatty acids, the transesterification process is more challenging (Sajjadi et al., 2016). Limited availability of animal fat compared to the world's biodiesel demands is further added to its disadvantages as a biodiesel feedstock.

\section{Oleaginous Microbes}

Oleaginous microorganisms are the microbes that accumulate lipid that is more than $20 \%$ of their dry weight based on stress condition, i.e., higher carbon and low nitrogen sources (Ratledge and Wynn, 2002; Meng et al., 2009), and may reach up to $70 \%$ or more providing the stress conditions (Rossi et al., 2011). These microbes use various renewable materials and convert them into microbial oil, which is utilized further to produce biodiesel through transesterification (Ma et al., 2008; Pinzi et al., 2013). The microbial oil is also termed as single-cell oil. The first single-cell oil was commercially produced way back in 1985 using filamentous fungus Mucor circinelloides, but its utilization for biodiesel production was not in thought at that time (Ratledge, 2004).

The general scheme of biodiesel production from OMs is culturing of microbes, biomass harvesting, drying, lipid extraction, and transesterification of the obtained lipid (Kumar et al., 2013). OM-based biodiesel production has a number of advantages such as overcoming the food vs. fuel crisis, shorter incubation time compared to plant and animal resources, independence of lipid production from variation of season, climate, and geography (Gujjala et al., 2017), and year-round culturing of OMs and microbial oil production. Additionally, the microbial oil has comparable composition and caloric value to those extracted from animal and plant resources, and low viscosity. Furthermore, OMs can be utilized to convert inexpensive agro-industrial wastes and even municipal wastes to microbial oil with similar quality as many high-value lipids (Cho and Park, 2018). Inexpensive lignocellulosic wastes may serve as a potential source for microbial oil production. However, lower lipid yield and tolerance against the degradation products generated out of lignocellulosic's pretreatment process are among the major bottlenecks for economical production of microbial oil or single-cell oil (Jin et al., 2015). OMs belong to different microbial families, namely, microalgae, yeast, filamentous fungi or molds, and bacteria (Ma, 2006).

Currently, microalgae-based biodiesel is the focus of research, as it may provide sufficient oil as feedstock for global consumption and produce biodiesel yields far higher than those recorded per hectare from plant feedstock (Zuccaro et al., 2020). Furthermore, they have the potential to mitigate land use and food vs. fuel conflicts and be cultivated in habitats that are not favorable for energy crops. They are also able to reduce the greenhouse effect via $\mathrm{CO}_{2}$ sequestration (Chisti, 2007). The lipid content in microalgae usually varies from 20 to $50 \%$ of the dry cellular weight, and it may increase up to $90 \%$ providing certain conditions (Adachi et al., 2011; Papanikolaou and Aggelis, 2011; Table 1). Considering the usual value of $30 \%$ dry weight for microalgal cell lipid content resulted in microalgal oil production of 4.5-7.5 t/ha/year (Tsukahara and Sawayama, 2005). It is much higher in comparison to the soybean, rapeseed, palm, and jatropha oil production, which are $0.4,1.4,1.6,3.6$, and $4.1 \mathrm{t} / \mathrm{ha} /$ year, respectively (Chisti, 2007; Lam and Lee, 2012).

Based on the modes of nutrition, microalgae are classified into heterotrophic, autotrophic, and mixotrophic, which imply that they have different metabolic pathways. In heterotrophic mode, organic compounds would serve as carbon sources that can be utilized for growth, which is advantageous in terms of higher productivity and concentration. In autotrophic regime, microalgae obtain carbon source from carbon dioxide, which is reduced with the help of light energy and releases $\mathrm{O}_{2}$. Predominantly, most of the microalgae confine to this category with minimal requirement of vitamins and organic compounds for growth. Mixotrophy mode comprises utilizing both organic carbon source and $\mathrm{CO}_{2}$ as substrates for growth by photosynthesis and cell respiration pathways. Cell growth pattern in mixotrophy is similar to heterotrophic mode as the latter 
growth is the sum of autotrophic and heterotrophic modes and results in higher productivity (Aratboni et al., 2019).

High production cost of microalgae-based biodiesel is the main hurdle for microalgae to be used as a suitable feedstock. As per literature, production cost of microalgal oil is 5.3-8.0 USD per liter (Pinzi et al., 2013). The major factors for the high production cost of microalgal oil include the biomass productivity, lipid content, production scales, and cost of oil recoveries from biomass (Balat, 2011). Heterotrophic growth and mixotrophic growth have great advantage of higher biomass and lipid productivity, but providing inexpensive suitable organic carbon source is one of the major limitations and hence one of the major factors for high production cost of microalgaebased biodiesel. Lignocellulosic wastes that are available in plenty presented as one of the options for cheap organic carbon source for microalgal growth (Chandel et al., 2020).

Molds or filamentous fungi are OMs that can store lipid up to $80 \%$ of their biomass composition (Pinzi et al., 2013). Many species of oleaginous fungus have been studied in recent years. These microbes can be grown on renewable carbon sources including lignocellulosics-based and usually their lipid has more amounts of unsaturated fatty acids compared to yeast (Hui et al., 2010; Papanikolaou and Aggelis, 2011; Economou et al., 2012; Papanikolaou and Aggelis, 2019). High lipid content and utilizing renewable carbon source for their growth favored oleaginous fungus to be a potential candidate of biodiesel feedstock (Table 2). Additionally, in contrast to microalgae, they can grow in the traditional bioreactors that will result in the reduction in production (biomass and oil) cost. Regardless, fungal oil utilization to produce biodiesel is still at laboratory scale.

Many yeast species (approximately 30 species) have already been recognized as oleaginous, and this list is continuously increasing (Luis et al., 2016). Mostly, these species have suitability for large-scale fermentation and are also amenable to genetic improvement (Athenaki et al., 2018). Oleaginous yeasts are found to store lipid up to $70 \%$ under conditions with nutrient limitation (Subramanian et al., 2010). They have faster growth compared to microalgae and contain triglycerides as the majority of the lipids (Leesing and Karraphan, 2011). Yeast oil production is found to be costlier than vegetable oil production because of the expensive commercial substrate; hence, selecting oleaginous yeast species that can grow using cheap substrate is crucial (Table 3).

Lignocellulosic waste is one of the cheap carbon sources that have been used for producing yeast oil using various yeast species in a number of studies. Recently, potentiality of oleaginous yeast for lipid production has been reviewed by Sreeharsha and Mohan (2020). However, yeast oil availability for commercial utilization is not yet reached.

Bacteria are having the properties of high growth rate and ease of genetic manipulation, which can be positively exploited for high microbial oil production. Generally, bacteria are not known for high lipid accumulation except some species, for example, Rhodococcus, Streptomyces, and Mycobacterium (Zuccaro et al., 2020). The actinomycetes are reported to have accumulation of fatty acid up to $70 \%$ of their cell dry weight (Kalscheuer et al., 2006). Genetic engineering in bacteria resulted in many high-lipid yielding species. It was reported that genetic changes in Escherichia coli led to $2.5 \mathrm{~g} / \mathrm{L}$ of fatty acid production ( $\mathrm{Lu}$ et al., 2008). Furthermore, many bacteria can be grown using lignocellulosic-based substrate as a carbon and energy source.

The bacteria Rhodococcus opacus, which has the ability to store more than $80 \%$ triglycerides (triglyceride transesterification leads to biodiesel or FAME formation) of its dry biomass, was grown solely on cob waste and achieve triglyceride production up to $59.26 \mathrm{mg} / \mathrm{L} /$ day (Alvarez and Steinbüchel, 2002). Also, R. opacus DSM1069 can degrade and live on lignin-derived compounds like coniferyl alcohol (Eggeling and Sahm, 1980). Utilization of lignocellulosic hydrolysates by numbers of other bacterial species including genetically engineered ones has also been reported in the literature for lipid production (Kumar et al., 2020b; Table 4). There are also reports on microbial oil production using algal-bacterial consortia (Zhang et al., 2020). Nonetheless, bacterial oil production is in infant stages at laboratory scale only, and commercial biodiesel production from bacteria is still a far distant story.

\section{LIGNOCELLULOSICS AND THEIR POTENTIAL FOR BIODIESEL PRODUCTION}

Lignocellulosics are considered among the most promising alternatives to fossil resources (Keegan et al., 2013; Shaheena et al., 2019), as they are generated from available atmospheric $\mathrm{CO}_{2}$, water, and sunlight through biological photosynthesis. They are sustainable sources of organic carbon and account for excess of $90 \%$ of worldwide plant biomass, corresponding to annual biomass of approximately $200 \times 10^{9}$ tons (Kuhad and Singh, 1993). LCB resources and their division are not well-defined. They can be categorized into four classes, viz., agricultural residues, forest residues, herbaceous grass and weeds, and industrial and municipal waste (Kumar et al., 2020c). Agricultural residues are observed to be the largest lignocellulosic resource (Yousuf, 2012). They include all the food crop residues and non-food crop residues. Wheat straw, rice straw, corn residues, and sugarcane bagasse are the major contributors of the agricultural residues.

Worldwide annual availability of wheat straw, rice straw, corn straw, and sugarcane bagasse residues are estimated to be 354.34 , $731.3205,128.02$, and 180.73 million tons (Mt), respectively (Saini et al., 2015). In Indian scenario, annual generation of the total agricultural crop residues is approximately $500 \mathrm{Mt}$, while around $140 \mathrm{Mt}$ are surplus crop residues, out of which $90 \mathrm{Mt}$ are surplus cereal residues (Bhuvaneshwari et al., 2019). Many countries especially European countries and the United States cultivate non-food crops or energy crops for biofuel production; the residues generated out of these crops are parts of agricultural residues. A study suggested that approximately $2.5 \mathrm{M}$ ha of land were used for energy crops' cultivation with $80-85 \%$ of rapeseed crops by European Union member countries in the year 2005 (Yousuf, 2012).

Herbaceous grasses and weeds can become agriculture residues, as they come out from agricultural fields and/or marginal lands. The second largest lignocellulosic resource is 
considered to be forest residues (Yousuf, 2012; Kumar et al., 2021). Usually, forest residues are referred to the parts of trees that are inappropriate for saw logs such as branches, dead wood, foliage, and treetops (Hossain and Badr, 2007). Tree fallings, residues from wood processing, and recycled wood can also be included in this group. Food industries and many other industries based on plants and plant products produce lignocellulosic wastes that can be utilized for microbial oil production. Municipal wastes also contain lignocellulosic components and hence can serve as a feedstock for microbial oil production.

Considering the commercial perspective of the biodiesel, generally, $40-80 \%$ of total production cost is incurred on substrate acquisition. Lignocellulosics, being the most abundant biorenewable biomass resource in the world (Somerville et al., 2010; Zhou et al., 2011) and economically cheap, can serve as a potential alternative for the cost-effective microbial oil production (Yousuf, 2012) leading to biodiesel production. From an economic point of view, lignocellulosics can be produced quickly and at a lower cost than other biofuel feedstocks (Huber, 2008). On the contrary, biofuels, particularly biodiesel, polymers, and biorefinery production from LCB are a great challenge owing to biomass recalcitrance of the lignin polymer (Himmel et al., 2007; Zhou et al., 2011). To reduce the recalcitrance, there is a requirement of pretreatment process that may include chemical, physical, or biological method. Prior to the pretreatment of LCB, the biomass needs to be processed by subjecting it to milling, which might cost up to $5 \%$ of the investment. Pretreatment of lignocellulosics resulted in the generation of various compounds as by-products such as furan aldehyde (furfural, 5-hydroxymethylfurfural), aliphatic carboxylic acids (acetic acid, formic acid, levulinic acid), and aromatic carboxylic acids (cinnamic and benzoic acid derivatives), which are detrimental to the growth of the microorganism involved in the bioprocessing for lipid production (Huang et al., 2009; Jönsson and Martín, 2016; Poontawee et al., 2017; Llamas et al., 2020; Valdés et al., 2020).

Effects of these inhibitors on OMs' physiology have been studied, and interestingly, it was observed that OMs are tolerant to inhibitors, and some are even having degradation properties such as Trichosporon cutaneum, which converts furfural and hydroxymethylfurfural (HMF) to their corresponding alcohol. In addition, it degraded formic acid and acetic acid (Chen et al., 2009; Wang et al., 2016; Poontawee et al., 2017; Valdés et al., 2020). Furthermore, acetic acid was observed to be the substrate and stimulator for lipid production by a number of OMs (Poontawee et al., 2017; Llamas et al., 2020). It was also found that microbes having a natural tolerant property against the inhibitors are not very efficient and rather have a restricted ability to convert sugars into lipid-rich biomass (Valdés et al., 2020). This can be overcome by genetically manipulating the OMs, which is not much difficult due to evolution and advancement of genetic engineering technology.

To address this problem, extensive research efforts have been made; as a result, several promising biorefinery technologies and demonstration plants using non-food cellulosic biomass feedstocks have been increasing (Cherubini and Strømman, 2011; Chandel et al., 2018).

\section{Structural Features of Lignocellulosics for Biodiesel Production}

Lignocellulosic biomass are composed of cellulose, hemicellulose, and lignin polymers as major components with percent dry weight of $30-35 \%, 20-25 \%$, and $15-20 \%$, respectively (Haghighi et al., 2013; Uthandi et al., 2021). This composition of lignocellulosics varies on the variation of their geographical location, growing conditions, and age (Pérez et al., 2002). Kumar et al. (2020e) have presented an exhaustive list of LCBs with their composition as dry weight percentage of lignin, cellulose, and hemicellulose. Biodiesel production from LCBs consists of four important steps such as delignification, saccharification, fermentation with OMs for higher lipid synthesis, and subsequent conversion to transesterification (Zhao et al., 2008; Kumar et al., 2017c).

Lignin polymer is a non-carbohydrate fraction that consists of phenyl propionic moieties and situated in the primary cell wall (Yousuf, 2012; Banerjee et al., 2019a). Lignin is made up of coniferyl alcohol, coumaryl alcohol, and sinapyl alcohol units bonded with varied ether bonds and imparts tensile strength, resistance against microbial attack, and impermeability. Owing to its (lignin) close association with cellulose microfibrils, the former acts as a barrier to microbial and enzymatic hydrolysis (Chintagunta et al., 2017). Lignin content varies in different feedstocks that need to abate through a delignification step for easy access of cellulose and hemicellulose polymers (Galbe and Zacchi, 2002).

In plant cell structure, cellulose polymer occupies a major proportion, which is made up of D-glucose moieties linked by $\beta$ 1,4-glycosidic bonds with a degree of polymerization of 10,000 or even higher. Cellulose polymers are packed into microfibrils through Van der Waals forces and hydrogen bonds. Owing to this bonding and structural confirmity, cellulose manifests tensile strength to cell wall, chemical stability, crystallinity, and resistance to microbial degradation (Himmel et al., 2007; Banerjee et al., 2017). Due to the cellulose inherent property, LCBs show recalcitrance behavior (Banerjee et al., 2019b).

Unlike cellulose polymer, hemicellulose is made up of several monomer units such as D-galactose, D-mannose, $\mathrm{D}$-xylose, D-glucose, D-glucuronic acid, L-arabinose, and 4-Omethyl-D-glucuronic that have an amorphous structure with a degree of polymerization lower than 200 (Chandel et al., 2020). Hemicellulose is an abundant polymer next to cellulose, which varies in composition from one feedstock to another. For example, in softwood, hemicelluloses are composed of gluco-mannan, while in grasses and agro-residues (straw), hemicelluloses are made up of xylan (Kumar et al., 2020a). Hemicelluloses form a complex network by linking with lignin and cellulose microfibrils that impart mechanical strength and sensitivity to thermal and chemical treatments (Banerjee et al., 2019a).

Efficient hydrolysis (saccharification) requires removal of at least $50 \%$ of hemicellulose for increased cellulose digestibility. However, treatment parameters should optimize meticulously for abatement of furfurals and HMFs that inhibit the fermentation process. With an objective of maximum sugar recovery, in general, the pretreatment 
conditions are compromised, and depending on the treatment, hemicellulose may be obtained as either solid or liquid fractions (Banerjee et al., 2017).

\section{BIOCONVERSION OF LIGNOCELLULOSIC BIOMASS TO BIODIESEL PRODUCTION}

The intricacy in the use of the LCB is due to the presence of physical barriers formed by the lignin that prevents the penetration of hydrolytic enzymes and access the cellulosic fraction of the biomass (Kucharska et al., 2018). Thus, the processing of LCB to biodiesel is complicated and includes several unit operations: pretreatment/depolymerization, hydrolysis/saccharification, culturing the OMs for lipid production, and transesterification. Each unit process is

TABLE 1 | Lipid production by oleaginous microalgae using lignocellulosic substrates.

\begin{tabular}{|c|c|c|c|}
\hline $\begin{array}{l}\text { Oleaginous } \\
\text { microalgae }\end{array}$ & Substrate & $\begin{array}{l}\text { Lipid } \\
\text { production }\end{array}$ & References \\
\hline $\begin{array}{l}\text { Chlorella } \\
\text { pyrenoidosa }\end{array}$ & $\begin{array}{l}\text { Rice straw } \\
\text { enzymatic } \\
\text { hydrolysate }\end{array}$ & $\begin{array}{l}1.55 \mathrm{~g} / \mathrm{L}^{\mathrm{a}} \\
53.6 \% \mathrm{~b}^{\mathrm{a}}\end{array}$ & Li et al., 2001 \\
\hline $\begin{array}{l}\text { Chlorella } \\
\text { protothecoides }\end{array}$ & $\begin{array}{l}\text { Cassava starch } \\
\text { enzymatic } \\
\text { hydrolysate, } \\
\text { corn powder } \\
\text { enzymatic } \\
\text { hydrolysate }\end{array}$ & $\begin{array}{l}2.14 \mathrm{~g} / \mathrm{L}^{\mathrm{a}} \\
22 \pm 55.2 \%{ }^{\mathrm{b}}\end{array}$ & $\begin{array}{l}\text { Xu et al., 2006; } \\
\text { Wei et al., } \\
\text { 2009; Lu et al., } \\
2010\end{array}$ \\
\hline Chlorella vulgaris & $\begin{array}{l}\text { Wheat bran } \\
\text { enzymatic } \\
\text { hydrolysate }\end{array}$ & $\begin{array}{l}\text { N.A g/ } \text { L }^{\mathrm{a}} \\
0.6 \pm 0.9 \%{ }^{\mathrm{b}}\end{array}$ & $\begin{array}{l}\text { El-Sheekh } \\
\text { et al., } 2012\end{array}$ \\
\hline $\begin{array}{l}\text { Schizochytrium } \\
\text { limacinum }\end{array}$ & $\begin{array}{l}\text { Sweet sorghum } \\
\text { juice (squeezed } \\
\text { by a mill) }\end{array}$ & $\begin{array}{l}2.15 \pm 4.95 \mathrm{~g} / \mathrm{L}^{\mathrm{a}} \\
55.3 \pm 70.5 \%^{\mathrm{b}}\end{array}$ & $\begin{array}{l}\text { Liang et al., } \\
2010\end{array}$ \\
\hline $\begin{array}{l}\text { Schizochytrium } \\
\text { mangrovei }\end{array}$ & $\begin{array}{l}\text { Food waste } \\
\text { hydrolysate }\end{array}$ & $\begin{array}{l}3.52 \mathrm{~g} / \mathrm{L}^{\mathrm{a}} \\
16.4 \%^{\mathrm{b}}\end{array}$ & $\begin{array}{l}\text { Pleissner et al., } \\
2013\end{array}$ \\
\hline $\begin{array}{l}\text { Chlorella } \\
\text { protothecoides }\end{array}$ & $\begin{array}{l}\text { Sugarcane } \\
\text { bagasse } \\
\text { hydrolysate }\end{array}$ & $5.8 \mathrm{~g} / \mathrm{L}^{\mathrm{a}} 34.0 \%^{\mathrm{b}}$ & Mu et al., 2015 \\
\hline $\begin{array}{l}\text { Nannochloropsis } \\
\text { sp. }\end{array}$ & $\begin{array}{l}\text { Palm oil mill } \\
\text { effluent }\end{array}$ & $3.2 \mathrm{~g} / \mathrm{L}^{\mathrm{a}} 11.0 \% \mathrm{o}^{\mathrm{b}}$ & $\begin{array}{l}\text { Cheirsilp et al., } \\
2017\end{array}$ \\
\hline $\begin{array}{l}\text { Auxenochlorella } \\
\text { protothecoides }\end{array}$ & $\begin{array}{l}\text { Organosolv/ } \\
\text { steam } \\
\text { explosion } \\
\text { pretreated } \\
\text { Birch biomass }\end{array}$ & $5.7 \mathrm{~g} / \mathrm{L}^{\mathrm{a}} 66 \%^{\mathrm{b}}$ & $\begin{array}{l}\text { Patel et al., } \\
2018\end{array}$ \\
\hline $\begin{array}{l}\text { Auxenochlorella } \\
\text { protothecoides }\end{array}$ & $\begin{array}{l}\text { Organosolv/ } \\
\text { steam } \\
\text { explosion } \\
\text { pretreated } \\
\text { Spruce } \\
\text { biomass }\end{array}$ & $5.3 \mathrm{~g} / \mathrm{L}^{\mathrm{a}} 63 \%{ }^{\mathrm{b}}$ & $\begin{array}{l}\text { Patel et al., } \\
2018\end{array}$ \\
\hline $\begin{array}{l}\text { Schizochytrium } \\
\text { sp. }\end{array}$ & $\begin{array}{l}\text { Sugarcane } \\
\text { bagasse } \\
\text { hydrolysate }\end{array}$ & $\begin{array}{l}\text { N.A g/ } \text { L }^{\mathrm{a}} \\
45.15 \%^{\mathrm{b}}\end{array}$ & $\begin{array}{l}\text { Nguyena et al., } \\
2018\end{array}$ \\
\hline
\end{tabular}

${ }^{a}$ Lipid yield, ${ }^{b}$ Lipid content (\% $\left.w / W\right)$. discussed extensively with a special emphasis on the various techniques involved in it.

\section{Lignin Depolymerization}

Pretreatment of the LCB is done to remove lignin and achieve maximum hydrolysis of cellulose and hemicellulose components for the production of fermentable sugars. This process reduces the crystallinity of the cellulose, increases the porosity, and improves the access of chemicals and hydrolytic enzymes toward the holocelluloses for effective hydrolysis of biomass (Jacob et al., 2016). A multitude of pretreatment methods have been developed in the last few decades where an ideal pretreatment process should have the features such as complete saccharification of the holocelluloses, minimum loss of sugars, by-product formation, and energy consumption. There are various pretreatment techniques that include physical, chemical, physicochemical, and biological pretreatments for lignin removal from LCB (Table 5).

The mechanical/physical pretreatment methods, viz., irradiation, pyrolysis, extrusion, and pulsed electric field, reduce the crystallinity, particle size, and degree of polymerization and increase the available surface area for effective action of hydrolytic enzymes. Being energy intensive, the physical pretreatment is not viable at industrial scale. Chemical pretreatment methods include alkaline $\left(\mathrm{NaOH}, \mathrm{KOH}, \mathrm{K}_{2} \mathrm{CO}_{3}, \mathrm{CaO}\right.$, and $\left.\mathrm{MgO}\right)$, acid $\left(\mathrm{H}_{2} \mathrm{SO}_{4}, \mathrm{H}_{3} \mathrm{PO}_{4}\right.$, and $\mathrm{HCl}$, zeolite, and $\mathrm{SiO}_{2}-\mathrm{Al}_{2} \mathrm{O}_{3}$ oxides), organosolv (methanol, acetone, and ethylene glycol), and ionic liquid (IL) $\{1$-butyl-3-methylimidazolium chloride $[(\mathrm{Bmim}) \mathrm{Cl}]\}$ pretreatment (Baruah et al., 2018).

TABLE 2 | Lipid production by oleaginous molds using lignocellulosic substrates.

\begin{tabular}{|c|c|c|c|}
\hline $\begin{array}{l}\text { Oleaginous } \\
\text { molds }\end{array}$ & Substrate & Lipid production & References \\
\hline $\begin{array}{l}\text { Mortierella } \\
\text { isabellina }\end{array}$ & $\begin{array}{l}\text { Corn stover } \\
\text { enzymatic } \\
\text { hydrolysate, } \\
\text { sweet sorghum }\end{array}$ & $\begin{array}{l}0.016 \pm 0.11 \mathrm{mg} / \mathrm{gds}^{\mathrm{a}} \\
29.47 \pm 38.36 \%^{\mathrm{b}}\end{array}$ & $\begin{array}{l}\text { Economou } \\
\text { et al., 2011; } \\
\text { Ruan et al., } \\
2012\end{array}$ \\
\hline $\begin{array}{l}\text { Microsphaeropsis } \\
\text { sp. }\end{array}$ & Wheat straw & $80 \mathrm{mg} / \mathrm{gds}^{\mathrm{a}} 10.2 \% \mathrm{~b}$ & $\begin{array}{l}\text { Peng and } \\
\text { Chen, } 2008\end{array}$ \\
\hline $\begin{array}{l}\text { Aspergillus } \\
\text { oryzae }\end{array}$ & $\begin{array}{l}\text { Wheat } \\
\text { straw + bran }\end{array}$ & $62.9 \mathrm{mg} / \mathrm{gds}^{\mathrm{a}}$ N.A. $\%^{\mathrm{b}}$ & Hui et al., 2010 \\
\hline $\begin{array}{l}\text { Colletotrichum } \\
\text { sp. }\end{array}$ & $\begin{array}{l}\text { Rice } \\
\text { straw + wheat } \\
\text { bran }\end{array}$ & $68.2 \mathrm{mg} / \mathrm{gds}^{\mathrm{a}}$ N.A. $\%^{\mathrm{b}}$ & Dey et al., 2011 \\
\hline Alternaria sp. & $\begin{array}{l}\text { Rice } \\
\text { straw + wheat } \\
\text { bran }\end{array}$ & $60.3 \mathrm{mg} / \mathrm{gds}^{\mathrm{a}}$ N.A. $\%^{\mathrm{b}}$ & Dey et al., 2011 \\
\hline $\begin{array}{l}\text { Mucor } \\
\text { Circinelloides } \\
\text { Q531 }\end{array}$ & $\begin{array}{l}\text { Mulberry } \\
\text { branches }\end{array}$ & $\begin{array}{l}42.43 \pm 4.01 \mathrm{mg} / \mathrm{gds}^{\mathrm{a}} \\
28.8 \pm 2.85 \%{ }^{\mathrm{b}}\end{array}$ & $\begin{array}{l}\text { Qiao et al., } \\
2018\end{array}$ \\
\hline $\begin{array}{l}\text { Phanerochaete } \\
\text { Chrysosporium } \\
\text { ATCC } 24725\end{array}$ & $\begin{array}{l}\text { Wheat bran, } \\
\text { corn straw and } \\
\text { glucose mixture }\end{array}$ & $>40 \%{ }^{b}$ & Liu et al., 2019 \\
\hline $\begin{array}{l}\text { Mucor } \\
\text { circinelloides }\end{array}$ & $\begin{array}{l}\text { Hydrolyzed } \\
\text { whey } \\
\text { permeates }\end{array}$ & $32 \% \mathrm{~b}$ & $\begin{array}{l}\text { Chan et al., } \\
2020\end{array}$ \\
\hline
\end{tabular}

a Lipid yield (mg/g dry substrate), b Lipid content (\% w/w). 
TABLE 3 | Lipid production by oleaginous yeast using lignocellulose substrates.

\begin{tabular}{|c|c|c|c|}
\hline Oleaginous yeast & Substrate & Lipid production & References \\
\hline $\begin{array}{l}\text { Cryptococcus } \\
\text { curvatus }\end{array}$ & $\begin{array}{l}\text { Corncob } \\
\text { hydrolysate, } \\
\text { sweet sorghum } \\
\text { bagasse } \\
\text { enzymatic } \\
\text { hydrolysate }\end{array}$ & $\begin{array}{l}10.83 \mathrm{~g} / \mathrm{L}^{\mathrm{a}} \\
61 \pm 73.26 \% \mathrm{~b}\end{array}$ & $\begin{array}{l}\text { Liang et al., } \\
\text { 2012; Chang } \\
\text { et al., } 2015\end{array}$ \\
\hline Lipomyces starkeyi & $\begin{array}{l}\text { Corncob acid } \\
\text { hydrolysate, } \\
\text { sugarcane } \\
\text { bagasse acid } \\
\text { hydrolysate }\end{array}$ & $\begin{array}{l}8.1 \mathrm{~g} / \mathrm{L}^{\mathrm{a}} \\
26.9 \pm 55 \% \mathrm{~b}\end{array}$ & $\begin{array}{l}\text { Huang et al., } \\
\text { 2014; Xavier } \\
\text { et al., } 2017\end{array}$ \\
\hline $\begin{array}{l}\text { Rhodosporidium } \\
\text { toruloides }\end{array}$ & $\begin{array}{l}\text { Jerusalem } \\
\text { artichoke, } \\
\text { cassava starch } \\
\text { enzymatic } \\
\text { hydrolysate }\end{array}$ & $\begin{array}{l}14 \pm 39.6 \mathrm{~g} / \mathrm{L}^{\mathrm{a}} \\
43.3 \pm 63.4 \%^{\mathrm{b}}\end{array}$ & $\begin{array}{l}\text { Zhao et al., } \\
\text { 2010; Wang } \\
\text { et al., } 2012\end{array}$ \\
\hline Rhodotorula glutinis & $\begin{array}{l}\text { Corncob acid } \\
\text { hydrolysate; } \\
\text { wheat straw acid } \\
\text { hydrolysate }\end{array}$ & $\begin{array}{l}1.4 \pm 5.5 \mathrm{~g} / \mathrm{L}^{\mathrm{a}} \\
11.86 \pm 36.4 \%{ }^{\mathrm{b}}\end{array}$ & Liu et al., 2015 \\
\hline $\begin{array}{l}\text { Trichosporon } \\
\text { cutaneum }\end{array}$ & $\begin{array}{l}\text { Corncob acid } \\
\text { and enzymatic } \\
\text { hydrolysates, } \\
\text { Diluted acid } \\
\text { pretreated and } \\
\text { biodetoxified corn } \\
\text { stover }\end{array}$ & $\begin{array}{l}9.8 \pm 12.3 \mathrm{~g} / \mathrm{L}^{\mathrm{a}} \\
32.1 \pm 40 \%^{\mathrm{b}}\end{array}$ & $\begin{array}{l}\text { Liu et al., 2012; } \\
\text { Gao et al., } \\
2014\end{array}$ \\
\hline Yarrowia lipolytica & $\begin{array}{l}\text { Sugarcane } \\
\text { bagasse and rice } \\
\text { bran hydrolysate }\end{array}$ & $\begin{array}{l}5.2 \pm 6.68 \mathrm{~g} / \mathrm{L}^{\mathrm{a}} \\
48 \pm 58.5 \%^{\mathrm{b}}\end{array}$ & $\begin{array}{l}\text { Tsigie et al., } \\
2012\end{array}$ \\
\hline $\begin{array}{l}\text { Cryptococcus } \\
\text { vishniaccii MTCC232 }\end{array}$ & Paper mill sludge & $7.8 \mathrm{~g} / \mathrm{L}^{\mathrm{a}} 53.4 \%^{\mathrm{b}}$ & $\begin{array}{l}\text { Deeba et al., } \\
2016\end{array}$ \\
\hline $\begin{array}{l}\text { Cutaneotrichosporon } \\
\text { cutaneum }\end{array}$ & $\begin{array}{l}\text { Corn stover } \\
\text { hydrolysate }\end{array}$ & $4-5 \mathrm{~g} / \mathrm{L}^{\mathrm{a}}$ & $\begin{array}{l}\text { Wang et al., } \\
2016\end{array}$ \\
\hline $\begin{array}{l}\text { Vishniacozyma } \\
\text { psychrotolerans }\end{array}$ & $\begin{array}{l}\text { Groundnut shell } \\
\text { hydrolysate }\end{array}$ & $46 \%{ }^{b}$ & $\begin{array}{l}\text { Deeba et al., } \\
2017\end{array}$ \\
\hline Rhodotorula glutinis & $\begin{array}{l}\text { Cassava bagasse } \\
\text { hydrolysate }\end{array}$ & $10.42 \mathrm{~g} / \mathrm{L}^{\mathrm{a}} 51 \%^{\mathrm{b}}$ & Liu et al., 2018 \\
\hline $\begin{array}{l}\text { Candida } \\
\text { phangngensis } \\
\text { PT1-17 }\end{array}$ & $\begin{array}{l}\text { Switchgrass } \\
\text { hydrolysate }\end{array}$ & $9.8 \mathrm{~g} / \mathrm{L}^{\mathrm{a}}$ & $\begin{array}{l}\text { Quarterman } \\
\text { et al., } 2018\end{array}$ \\
\hline $\begin{array}{l}\text { Rhodotorula } \\
\text { paludigenum }\end{array}$ & $\begin{array}{l}\text { Corncob } \\
\text { hydrolysate }\end{array}$ & $3.29 \mathrm{~g} / \mathrm{L}^{\mathrm{a}} 58 \%{ }^{\mathrm{b}}$ & $\begin{array}{l}\text { Chaiyaso et al., } \\
2019\end{array}$ \\
\hline $\begin{array}{l}\text { Meyerozyma } \\
\text { guilliermondii }\end{array}$ & $\begin{array}{l}\text { Sugarcane } \\
\text { bagasse } \\
\text { hydrolysate }\end{array}$ & $37.99 \pm 0.003 \%^{b}$ & $\begin{array}{l}\text { Ananthi et al., } \\
2019\end{array}$ \\
\hline Pichia kudriavzevii & $\begin{array}{l}\text { Rice husk } \\
\text { hydrolysate }\end{array}$ & $28.57 \pm 0.009 \%^{b}$ & $\begin{array}{l}\text { Ananthi et al., } \\
2019\end{array}$ \\
\hline Naganishia albida & $\begin{array}{l}\text { Biowaste } \\
\text { hydrolyzed by } \\
\text { microbes }\end{array}$ & $13.5 \mathrm{~g} / \mathrm{L}^{\mathrm{a}} 20 \%^{\mathrm{b}}$ & $\begin{array}{l}\text { Sathiyamoorthi } \\
\text { et al., } 2019\end{array}$ \\
\hline $\begin{array}{l}\text { Cutaneotrichosporon } \\
\text { dermatis }\end{array}$ & $\begin{array}{l}\text { Corn stover } \\
\text { hydrolysate }\end{array}$ & $20.36 \mathrm{~g} / \mathrm{L}^{\mathrm{a}} 56 \%^{\mathrm{b}}$ & Yu et al., 2020 \\
\hline
\end{tabular}

a Lipid yield, ${ }^{b}$ Lipid content (\% w/W).

Physicochemical pretreatment is an integration of physical and chemical methods, and various methods included under this pretreatment are ammonia fiber explosion (AFEX), steam explosion, $\mathrm{CO}_{2}$ explosion, and hydrothermal methods.
Furthermore, the biological pretreatment of biomass is conducted using either microorganisms or enzymes. It requires low energy and mild operation conditions. A decrease in lignin content enhances the yield of fermentable sugars from holocelluloses. Through pretreatment, a significant fraction of lignin will be removed from the biomass that upon recovery is generally utilized as fuel for generation of heat and power. But there are certain fungal species and oleaginous bacteria that can utilize lignin as substrate for supporting their growth and lipid production (Kosa and Ragauskas, 2012).

Besides using suitable pretreatment methods to reduce the lignin content, research has been carried out to study the effect of lignin biosynthesis genes on the amount and composition of lignin. Various parameters such as modifications in the target gene and the degree of downregulation of the enzyme activity, efficiency of the silencing construct utilized, size of the gene family, and the redundancy within the gene family influence the degree of lignin reduction, for instance, modifying the genes encoding for transcription factors, oxidative enzymes, etc., and reducing the activity of steps involved in lignin biosynthetic pathway, starting from phenylalanine ammonia-lyase (PAL) up to cinnamyl alcohol dehydrogenase (CAD) results in variation in the lignin content and composition (Wang J. P. et al., 2018). Moreover, downregulation of the steps from cinnamate 4-hydroxylase $(\mathrm{C} 4 \mathrm{H})$ up to cinnamoyl-CoA reductase (CCR) drastically reduces the lignin content when compared with downregulation of ferulate 5-hydroxylase (F5H), caffeic acid $O$ methyltransferase (COMT), and CAD. Downregulation of the caffeic acid $\mathrm{O}$-methyltransferase gene modestly decreased the lignin content, reduced the syringyl:guaiacyl lignin monomer ratio, improved forage quality, and increased the ethanol yield by $38 \%$ in switchgrass (Fu et al., 2011). Reduced lignin content along with variation in the H/G/S ratios in the LCB affects the biomass processing efficiency. For example, increased level of $\mathrm{H}$ units reduces the length of lignin polymer and enhances the lignin removal from the biomass (Sykes et al., 2015). Besides, the processing efficiency of the biomass can also be enhanced by incorporating certain molecules, for example, ferulic acid in CCR-deficient trees results in the formation of acetal bonds in the lignin polymer, which are easily cleaved in acidic biomass pretreatment (Van Acker et al., 2014).

\section{Saccharification of Lignocellulosic Biomass}

Saccharification is usually preceded by pretreatment of lignocellulosics to convert carbohydrate polymers efficiently into fermentable sugars. The efficiency of the process predominantly depends upon the pretreatment method, as improper maintenance of operating conditions during the process may lead toward the production of compounds having an inhibitory effect on the downstream processes. Commonly used techniques in hydrolysis of the cellulose fraction of biomass are chemical and enzymatic methods.

The chemical hydrolysis of polysaccharides in the biomass can take place in the presence of acid under high temperatures. It does not require pretreatment of the biomass and takes place at 
high rates. The drawbacks related to this method are formation of furfurals, low yield of sugars, and less economical feasibility of the process. The process can be made economical only through development of effective acid recovery techniques. Besides, the enzymatic hydrolysis is performed at low temperatures (45$50^{\circ} \mathrm{C}$ ) and pressure and mild $\mathrm{pH}$; high yield of fermentable sugar is obtained with low by-product formation without causing corrosion of equipment (Kucharska et al., 2020). Thus, high concentrations of enzymes are essential for cellulose hydrolysis, and their production needs knowledge of efficient microbial strains and economically feasible techniques.

Cellulose and hemicellulose conversion is catalyzed by cellulase and hemicellulase, which are complex enzymes. The subunits of cellulose include endoglucanases, exoglucanases, and $\beta$-glycosylases. Endoglucanase is involved in random digestion of internal $\beta$-1,4-glycosidic bonds, exoglucanase cleaves cellulose from either reducing or non-reducing ends, and $\beta$-glucosidase hydrolyzes cellobiose into glucose. Similarly, xylan-degrading enzymes include endoxylanases, $\beta$-xylosidases, $\alpha$-glucuronidase, $\alpha$-arabinofuranosidase, and acetoxylan esterase. Among the endo- $\beta$-1,4-xylanase hydrolyses, the $\beta-(1,4)$ linkages of the xylan give rise to xylooligosaccharides, which will be further hydrolyzed into xylose units by $\beta$-xylosidase (Kumar et al., 2017 c). Synergistic action of cellulases and hemicelluases will promote the conversion rate of holocelluloses into simple sugars. As each enzyme present in the cocktail has different optimal conditions, it is very difficult to determine optimal conditions for enzyme cocktail (Lopes et al., 2018).

\section{Lipid Biosynthesis}

The hydrolysate obtained through the saccharification process is used as carbon source by various microbes such as Gordonia sp., Mycobacterium tuberculosis, Chlorella sp., Rhodosporidium toruloides, Mortierella isabellina, etc. (Kumar et al., 2020c). Most of these OMs lack the cellulase and xylanase activity, and hence, they cannot directly utilize the polysaccharides present in the biomass. Thus, there is every need to hydrolyze the polysaccharides into fermentable sugars such as glucose and xylose and supplement them to the microbe as carbon source. OMs have the capacity to convert glucose and similar sugars to pyruvate, which is further used in the synthesis of lipids. The three physiological phases of de novo biosynthesis include (i) growth phase under balanced conditions, (ii) oleaginous phase under nitrogen-limited conditions, and (iii) reserved lipid turnover phase that occurs after depletion of carbon compounds in the growth medium. The carbon source is converted in cell mass through glycolysis and pentose phosphate pathway, but the depletion of essential nutrients induces oil accumulation. Furthermore, during the lipid turnover phase, the triacylglycerol (TAG) is degraded for the generation of energy required for the maintenance of the cell. Approximately $0.32 \mathrm{~g}$ of lipid/g of glucose and $0.34 \mathrm{~g}$ of lipid/g of xylose can be produced by these microbes (Ratledge, 1988). Furthermore, strains such as Rhodosporidium and Pseudozyma were reported to consume xylose, glucose, and fructose and xylose, glucose, and arabinose respectively (Patel et al., 2015; Tanimura et al., 2016). Besides, Wang Q. et al. (2018) and Spagnuolo et al. (2019) observed enhanced accumulation of saturated fatty acids upon employing consortia of OMs.

Apart from the concentration of nutrients, other factors responsible for lipid accumulation are temperature, $\mathrm{pH}$, culture agitation, and dissolved oxygen. It was reported that some microalgae accumulate high amounts of TAG under nitrogendeficient conditions (Yodsuwan et al., 2017). Several works reported that the presence of ammonium nitrogen in the medium favors lipid synthesis, whereas a few reported the improved lipogenesis in the presence of organic nitrogen (Fakas et al., 2008). Moreover, limitations of minerals, viz., iron, magnesium, zinc, phosphorus, nitrogen, in the culture medium induce lipid biosynthesis. It was also reported that $>30^{\circ} \mathrm{C}$, neutral and basic $\mathrm{pH}$, and 200-300 rpm enhance lipid production (Papanikolaou and Aggelis, 2011; Chaiyaso et al., 2019). Furthermore, reactive oxygen species (ROS) produced under stress may result in lipid peroxidation and denaturation of protein and DNA, but under balanced level, it promotes lipid production (Zhang et al., 2020).

Oleaginous microorganisms have the capacity of producing acetyl-CoA and nicotinamide adenine dinucleotide phosphate (NADPH) that are necessary for the synthesis of fatty acids. Excess carbon and nitrogen-deficit conditions induce the upregulation of AMP deaminase (AMPD), which cleaves adenosine monophosphate (AMP) to inosine monophosphate (IMP) and ammonia. Eventually, the concentration of AMP and activity of $\mathrm{NAD}^{+}\left(\mathrm{NADP}^{+}\right)$-depended isocitrate dehydrogenase (ICDH) will be downregulated. In mitochondria, in the presence of aconitase, the accumulated isocitrate will be isomerized to citrate, which will be transported into the cytoplasm in exchange for malate. The OMs exclusively synthesize ATP citrate lyase, which will convert citrate into acetyl-CoA and oxaloacetate. The acetyl-CoA is used as a precursor for the synthesis of fatty acid, whereas oxaloacetate will be converted into malate in the presence of malate dehydrogenase and transported into mitochondria (Ratledge and Wynn, 2002; Figure 1).

Lipid biosynthesis by OMs from lignocellulosics can be carried out through separate hydrolysis and lipid production (SHLP) where hydrolysis and lipid production take place separately in two steps; simultaneous saccharification and lipid production (SSLP) where saccharification and lipid production take place simultaneously in a reactor; and consolidated bioprocessing (CBP) where cellulase production, hydrolysis, and lipid production take place in one step (Figure 1). SHLP is characterized by inhibition of cellulase by glucose, leading toward a reduction in the yield of simple sugars. In the case of SSLP, the sugars released due to hydrolysis get assimilated by microorganisms, thereby reducing the inhibitory effect of glucose. SSLP is more economical than SHLP, as the process is completed in a single vessel, but processing needs a compromise with temperature, as the temperature requirements are different for hydrolysis and lipid production, which is the disadvantage of the process (Olofsson et al., 2008).

An industrially viable strain that can produce cellulase with high titer for hydrolyzing cellulose and even accumulate lipid is either isolated or designed by genetic engineering for its application in CBP. The strain is designed by incorporating genes responsible for cellulose degradation and high lipid 
accumulation. These OMs can be grown on the biomass hydrolysate for production of lipids by either solid state or submerged fermentation processes. The lipid yield produced by various OMs grown on lignocellulosic hydrolysate has been illustrated in Tables 4, 5. There are various strategies to improve the lipid yield from the OMs grown on lignocellulosic hydrolysate (Santek et al., 2018). They include:

- Development of strain that has industrial viability: Through metabolic engineering (ME), the strain should be developed in such a way that it should produce a high yield of lipids, be tolerant toward inhibitors generated during delignification of lignocellulosics, and exhibit heterologous expression of cellulase.

- Construction of efficient bioreactor design: The reactor should be configured at very low capital and operational costs.

- Improved pretreatment for lignocellulosics: Cost-effective pretreatment process with limited inhibitor formation and enhanced hydrolysis should be employed.

- Effective utilization of by-products formed during the process: During the process of biodiesel formation, there is a scope of generation of several by-products such as lignin, sophorolipids, pigments. These by-products can generate an additional income in the lipid biorefinery.

- Advances in the downstream process: Development of an efficient method for large-scale extraction of lipids in a costeffective way. Extraction of lipid from cell wet biomass is economical than extraction from dry biomass, as the cost incurred upon drying of biomass can be saved.

Apart from using various strategies for enhancing lipid production, advanced techniques such as microfluidics can be used to optimize the process parameters for production of lipids, transesterification, and quality assessment of blended biodiesel. Researchers have observed the synthesis of energy-rich lipid under yellow light (580 nm) (Shih et al., 2015). As the growth was not congenial, researchers exposed Cyclotella cryptica to alternative blue and yellow light for 15 and $8 \mathrm{~h}$, respectively, which led to rapid proliferation and production of higher neutral lipids. Yeh et al. (2016) developed a microfluidic platform with a large surface-to-volume ratio that drives the chemical reaction by enhancing the material interface. Soybean oil and methanol are the components that participate in the transesterification process. This methanol is passed coaxially into the pool of the oil wherein the methanol is surrounded by the oil, resulting in the reduction in ratio of methanol:oil (3:1). At 1, 1:2, and 1:3 ratios of methanol:oil, the oil conversion was $100,99.5$, and $98.6 \%$, respectively. The results infer that the oil:methanol is an essential parameter for enhancing the transesterification.

On the other hand, Kosa et al. (2018) used Duetz microtiter plate system in combination with Fourier transform infrared spectroscopy and multivariate analysis for high-throughput screening of efficiency of more than 100 Mucoromycota strains for production of high- and low-value lipids.

Upon considering the role of proteomics/transcriptomics for enhancing the production of lipids, in Nannochloropsis gaditana,
TABLE 4 | Lipid production by oleaginous bacteria using lignocellulose substrates.

\begin{tabular}{|c|c|c|c|}
\hline $\begin{array}{l}\text { Oleaginous } \\
\text { microbes }\end{array}$ & Substrate & Lipid production & References \\
\hline Gordonia sp. DG & Orange waste & $71 \%^{a}$ & $\begin{array}{l}\text { Gouda et al., } \\
2008\end{array}$ \\
\hline $\begin{array}{l}\text { Rhodococcus } \\
\text { opacus PD630 }\end{array}$ & Orange waste & $83 \%^{a}$ & $\begin{array}{l}\text { Voss and } \\
\text { Steinbuchel, } \\
2001\end{array}$ \\
\hline R. opacus Xsp8 & $\begin{array}{l}\text { Kraft hardwood } \\
\text { (hydrolysate) }\end{array}$ & $45.8 \%^{a}$ & $\begin{array}{l}\text { Kurosawa and } \\
\text { Sinskey, } 2013\end{array}$ \\
\hline $\begin{array}{l}\text { Rhodococcus } \\
\text { opacus }\end{array}$ & $\begin{array}{l}\text { Oxygen-pretreated } \\
\text { Kraft lignin }\end{array}$ & $14.2 \%^{\mathrm{a}}$ & Wei et al., 2015 \\
\hline $\begin{array}{l}\text { Rhodococcus } \\
\text { opacus }\end{array}$ & $\begin{array}{l}\text { Effluent from } \\
\text { lignocellulosic } \\
\text { pretreatment }\end{array}$ & $26.9^{a}$ & $\begin{array}{l}\text { Goswami et al., } \\
2017\end{array}$ \\
\hline
\end{tabular}

Lipid content $(\% w / w)$.

the macronutrient stress is associated with lipid remodeling. Significant modifications occurred in some lipid-related proteins, including increased expression of diacylyglycerol acyltransferase2 (DGAT) and lipid body proteins under N-starved conditions. Nitrogen starvation reduces growth and protein and chlorophyll contents concurrently increase neutral lipids, carbohydrates, and secondary carotenoids in various species. The effects of $\mathrm{P}$ deprivation are linked to remodeling of the lipid profile, where phosphorus-containing lipid classes are substituted for non-phosphorus lipids (Mühlroth et al., 2017).

Upon considering various OMs, viz., yeasts, fungi, microalgae, and bacteria, yeasts were regarded as the best candidate for higher lipid accumulation owing to their fast growth, high lipid accumulation, and easy scale-up (Younes et al., 2020). The lipid accumulated by the yeast generally contains fatty acids such as palmitic acid, myristic acid, oleic acid, stearic acid, linolenic acid, and linoleic acid (Fabiszewska et al., 2019). In order to obtain the lipid content from the microbes, there is a need that one should adopt an appropriate extraction method.

\section{LIPID EXTRACTION AND TRANSESTERIFICATION}

In order to extract the lipid from the microbe, the primary requisite is the disruption of the cell wall. Various techniques such as high-pressure homogenization, bead mill, ultrasound, pulsed electric field, osmotic shock, subcritical water hydrolysis, microwaves, enzymatic hydrolysis, autolysis, and chemical hydrolysis are generally used for cell disruption (Khot et al., 2020). Besides, hydroxyl radicals, nanoscalpels, and photocatalytically active amino clay-conjugated $\mathrm{TiO}_{2}$ are being used for cell disruption (Dong et al., 2016; Chintagunta et al., 2020). Furthermore, solvent extraction, pressing and solvent-integrated extraction, supercritical extraction, elevated temperature and pressure solvent extraction, electroporationassisted extraction, ultrasound-assisted extraction, and ionic liquid co-solvent extraction are used for extracting the lipids from the OMs. In the entire process of biodiesel synthesis, lipid extraction alone will incur up to $90 \%$ of the cost; hence, in 
TABLE 5 | Various methods of pretreatment and their effect of the lignocellulosic biomass.

\begin{tabular}{|c|c|c|c|c|}
\hline Pre-treatment & Technique & Effect on biomass & Yield & References \\
\hline $\begin{array}{l}\text { Mechanical } \\
\text { - } \text { Chipping } \\
\text { - } \text { Milling } \\
\text { - } \text { Grinding }\end{array}$ & $\begin{array}{l}\text { Vibratory ball milling, Ball milling, } \\
\text { Hammer milling, Colloid milling, Wet } \\
\text { disk milling }\end{array}$ & $\begin{array}{l}\text { Improves digestibility of the biomass } \\
\text { and increases surface area Reduction } \\
\text { in crystallinity of cellulose and degree of } \\
\text { polymerization }\end{array}$ & $\begin{array}{l}\text { Increase of } 5-25 \% \text { in yield of } \\
\text { sugars after hydrolysis }\end{array}$ & $\begin{array}{l}\text { Barakat et al., } \\
2015\end{array}$ \\
\hline $\begin{array}{l}\text { Microwave assisted size } \\
\text { reduction }\end{array}$ & $\begin{array}{l}\text { High-pressure microwave } \\
\text { pretreatment is operated in closed } \\
\text { reactors within the temperature } \\
\text { range from } 150 \text { to } 250^{\circ} \mathrm{C}\end{array}$ & $\begin{array}{l}\text { Molecular collisions due to dielectric } \\
\text { polarization generates thermal energy } \\
\text { that leads to disruption of the } \\
\text { lignocellulosic structure }\end{array}$ & $\begin{array}{l}\text { Highest methane yield of } \\
221 \mathrm{~mL} \cdot \mathrm{g}-\mathrm{sub}^{-1} \text { was obtained } \\
\text { from microwave pretreated } \\
\text { Hyacinthus spp. }\end{array}$ & $\begin{array}{l}\text { Zhao et al., } \\
2017\end{array}$ \\
\hline Steam explosion & $\begin{array}{l}\text { Exposure of lignocellulosics to hot } \\
\text { steam up to } 160-260^{\circ} \mathrm{C} \text {, } \\
\text { 0.69-4.38 MPa pressure for few } \\
\text { minutes }\end{array}$ & $\begin{array}{l}\text { Solubilization of hemicellulose leads to } \\
\text { formation of acid that catalyze } \\
\text { hydrolysis of soluble fractions Improved } \\
\text { exposure of cellulose to hydrolytic } \\
\text { chemicals and enzymes }\end{array}$ & $\begin{array}{l}\text { Facilitates upto } 90 \% \text { of } \\
\text { enzymatic hydrolysis }\end{array}$ & $\begin{array}{l}\text { Grous et al., } \\
1986\end{array}$ \\
\hline $\begin{array}{l}\text { Hot } \\
\text { water/aquasolv/uncatalyzed } \\
\text { solvolysis/aqueous } \\
\text { fractionation/ } \\
\text { hydrothermolysis }\end{array}$ & $\begin{array}{l}\text { Exposure of lignocellulosics to } \\
200-230^{\circ} \mathrm{C} \text { and high pressure for } \\
\text { few minutes }\end{array}$ & $40-60 \%$ of the biomass gets dissolved & $\begin{array}{l}4-22 \% \text { of cellulose, } 35-60 \% \text { of } \\
\text { lignin and entire hemicelluloses } \\
\text { is digested No formation of } \\
\text { toxic inhibitory compounds if } \\
\mathrm{pH} \text { is maintained between } 4 \\
\text { and } 7\end{array}$ & $\begin{array}{l}\text { Kumar et al., } \\
2009\end{array}$ \\
\hline $\begin{array}{l}\text { Ammonia fiber explosion } \\
\text { (AFEX) }\end{array}$ & $\begin{array}{l}\text { Biomass }(1 \mathrm{~kg}) \text { is treated with hot } \\
\text { liquid ammonia }(1-2 \mathrm{~kg}) \text { under high } \\
\text { pressure at } 90^{\circ} \mathrm{C} \text { for } 30 \mathrm{~min} \text {, } \\
\text { followed by sudden release of the } \\
\text { pressure }\end{array}$ & $\begin{array}{l}\text { Alters the structure of the biomass } \\
\text { Increases the water-holding capacity of } \\
\text { the biomass and its digestibility }\end{array}$ & $\begin{array}{l}\text { Increases the yield upon } \\
\text { hydrolysis by six folds }\end{array}$ & $\begin{array}{l}\text { Alizadeh } \\
\text { et al., } 2005\end{array}$ \\
\hline Acid & $\begin{array}{l}\text { Sulfuric acid }(0.2-2.5 \text { wt } \%) \text { is mixed } \\
\text { with biomass and the pretreatment } \\
\text { is carried out either at } 180^{\circ} \mathrm{C} \text { or } \\
\text { above for } 5 \text { min or } 120^{\circ} \mathrm{C} \text { for } \\
30-90 \text { min }\end{array}$ & $\begin{array}{l}\text { Hydrolyzes hemicellulose to its } \\
\text { constituent monomers Removal of } \\
\text { hemicellulose and lignin promotes } \\
\text { efficient hydrolysis of cellulose }\end{array}$ & $\begin{array}{l}\text { Acid pretreatment in } \\
\text { combination with efficient } \\
\text { hydrolysis, } 100 \% \text { recovery of } \\
\text { sugar from biomass is } \\
\text { achievable }\end{array}$ & $\begin{array}{l}\text { Mosier et al., } \\
2005\end{array}$ \\
\hline Alkaline & $\begin{array}{l}\text { Lignocellulosic biomass is soaked } \\
\text { in the solution containing } \\
\text { hydroxides of calcium/sodium, } \\
\text { potassium/ammonia }\end{array}$ & $\begin{array}{l}\text { Promotes degradation of glycosidic } \\
\text { side chains and ester linkages, leading } \\
\text { to structural alteration of lignin, partial } \\
\text { decrystallization and swelling of } \\
\text { cellulose. Solvation of hemicelluloses } \\
\text { and saponification of intermolecular } \\
\text { ester linkages, leads to enhanced } \\
\text { porosity of the biomass. }\end{array}$ & $\begin{array}{l}\text { At optimal conditions ( } 1.5 \% \\
\mathrm{NaOH} \text { solution, } 144 \mathrm{~h} \\
\text { incubation time and } 20^{\circ} \mathrm{C} \text { ), } \\
60 \% \text { lignin removal and } 80 \% \\
\text { release of hemicellulose sugar } \\
\text { (as xylose) took place from } \\
\text { wheat straw. }\end{array}$ & $\begin{array}{l}\text { Chen et al., } \\
2012\end{array}$ \\
\hline $\mathrm{CO}_{2}$ explosion & $\begin{array}{l}\text { At conditions above critical point of } \\
31^{\circ} \mathrm{C} \text { and } 7.39 \mathrm{MPa}, \mathrm{CO}_{2} \text { behaves } \\
\text { as a supercritical fluid and has } \\
\text { access to pores in biomass } \mathrm{CO}_{2} \\
\text { reacts with moisture to form } \\
\text { carbonic acid, which further } \\
\text { catalyzes biomass degradation }\end{array}$ & $\begin{array}{l}\text { Explosive release of pressure leads to } \\
\text { the disruption of hemicellulose and } \\
\text { cellulose structure and increases the } \\
\text { overall accessible area to enzymes. }\end{array}$ & $\begin{array}{l}\text { Supercritical } \mathrm{CO}_{2} \text { pretreatment } \\
\text { results in } 75 \% \text { yield of glucose } \\
\text { relative to its theoretical yield. }\end{array}$ & $\begin{array}{l}\text { Maurya et al., } \\
2015\end{array}$ \\
\hline Ozonolysis & $\begin{array}{l}\text { The terminal oxygen of ozone is } \\
\text { electron deficit and selectively } \\
\text { attacks substrates rich in electrons } \\
\text { such as lignin, while carbohydrates } \\
\text { mostly remain unaffected }\end{array}$ & $\begin{array}{l}\text { By ozonolysis, degradation is mostly } \\
\text { limited to lignin, while hemicellulose is } \\
\text { slightly affected and cellulose is } \\
\text { unaffected }\end{array}$ & $\begin{array}{l}\text { Removal of lignin ( } 60 \%) \text { through } \\
\text { ozonolysis, led to fivefold } \\
\text { increase enzyme hydrolysis rate } \\
\text { of wheat straw. }\end{array}$ & Li et al., 2015 \\
\hline Organosolv & $\begin{array}{l}\text { It operates at } 90-120^{\circ} \mathrm{C} \text { (for } \\
\text { grasses) and } 155-220^{\circ} \mathrm{C} \text { (for } \\
\text { wood), } 25-100 \text { min incubation time } \\
\text { Solvent and catalyst concentration } \\
\text { varies with the type of feedstock. }\end{array}$ & $\begin{array}{l}\text { The internal lignin and hemicellulose } \\
\text { bonds will be broken simultaneously }\end{array}$ & $\begin{array}{l}90 \% \text { hydrolysis of softwood } \\
\text { pulp cellulose took place in } \\
48 \text { h using the solvent, ethanol. }\end{array}$ & $\begin{array}{l}\text { Haghighi } \\
\text { et al., } 2013\end{array}$ \\
\hline Biological & $\begin{array}{l}\text { Deconstruction of lignin structure in } \\
\text { the cell wall using microbes and/or } \\
\text { enzymes under ambient conditions }\end{array}$ & $\begin{array}{l}\text { Microorganisms and the enzymes are } \\
\text { known for lignin and hemicellulose } \\
\text { removal with a very little effect on } \\
\text { cellulose }\end{array}$ & $\begin{array}{l}\text { Pretreatment of Bermuda grass } \\
\text { by Cyathus stercoreus resulted } \\
\text { in } 63-77 \% \text { of delignification } \\
\text { which leads to improved } \\
\text { production of fermentable } \\
\text { sugars }\end{array}$ & $\begin{array}{l}\text { Chaturvedi } \\
\text { and Verma, } \\
2013\end{array}$ \\
\hline
\end{tabular}


TABLE 5 | Continued

\begin{tabular}{|c|c|c|c|c|}
\hline Pre-treatment & Technique & Effect on biomass & Yield & References \\
\hline Ionic liquid & $\begin{array}{l}\text { Conditions maintained for carrying out } \\
\text { IL pretreatment are : } 100-150^{\circ} \mathrm{C} \text { and } \\
\text { biomass to ionic liquid ratio of } 1: 10 \\
(\mathrm{w} / \mathrm{w})\end{array}$ & $\begin{array}{l}\text { This method simultaneously dissolve lignin and } \\
\text { carbohydrates After pretreatment, cellulose can } \\
\text { be separated by addition of anti-solvents } \\
\text { followed by centrifugation and filtration } \\
\text { Significant changes occurs in cellulose } \\
\text { crystallinity, structure, composition, and surface } \\
\text { characteristics of the biomass }\end{array}$ & $\begin{array}{l}\text { Enhancement of biomass } \\
\text { digestibility More than } 90 \% \\
\text { conversion of cellulose to } \\
\text { sugars takes place }\end{array}$ & $\begin{array}{l}\text { Singh et al., } \\
2009\end{array}$ \\
\hline Oxidative & $\begin{array}{l}\text { Addition of oxidizing agents like } \\
\mathrm{O}_{2} / \mathrm{H}_{2} \mathrm{O}_{2} / \text { peracetic acid to the biomass } \\
\text { suspended in water }\end{array}$ & $\begin{array}{l}\text { The technique involves the removal of } \\
\text { hemicelluloses and lignin to improve the } \\
\text { accessibility of hydrolytic agents towards } \\
\text { cellulose }\end{array}$ & $\begin{array}{l}\text { Peracetic acid hydrolysis of } \\
\text { poplar and sugarcane bagasse } \\
\text { increased reducing sugar yield } \\
\text { upto } 98 \%\end{array}$ & $\begin{array}{l}\text { Tan et al., } \\
2010\end{array}$ \\
\hline
\end{tabular}

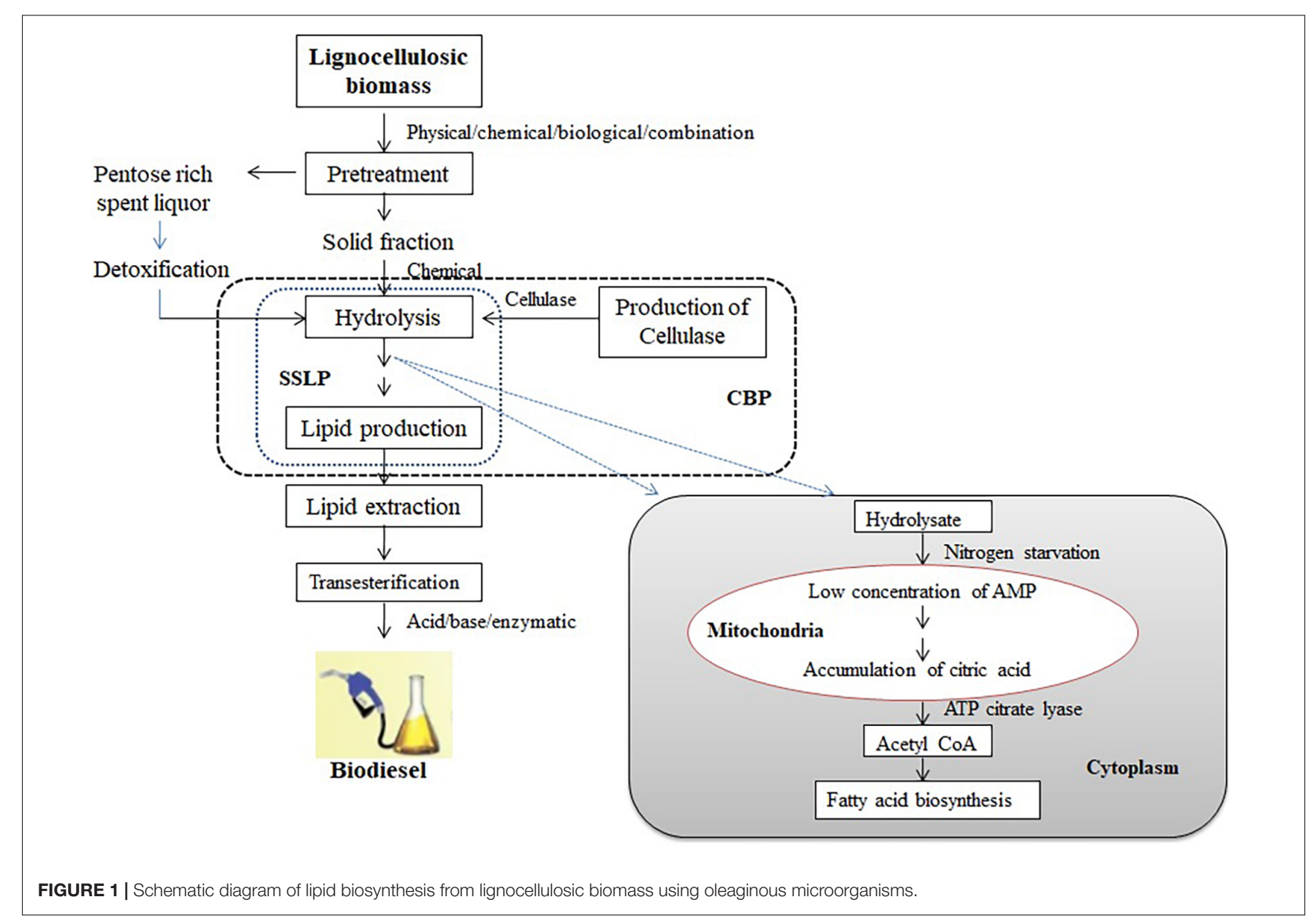

order to make the process economical, green solvent and green extraction techniques that can save time and energy and reduce solvent consumption are being used (Kumar et al., 2017b).

Even though the oleaginous biomass is rich in lipids, it also contains a large amount of proteins and carbohydrates. For instance, soybeans comprise 20\%(wt.) lipid, 20\%(wt.) carbohydrates, and nearly 40\%(wt.) proteins (Maddi et al., 2018). Even the lipid-rich strains of microalgae contain significant amounts of non-lipid component. In spite of applying the biomass remnants obtained after lipid extraction to the soil, it can be processed for the generation of value-added products such as gasoline and methane. The dry algal biomass residue can be pyrolyzed to oils that are suitable as transportation fuels. The wet biomass can be processed through hydrothermal means and anaerobic digestion for the production of diesel, gasoline, and methane. As neither the algal biomass nor the remnants contain lignin, the obtained bio-oil will not contain any phenolic oligomers. But the proteins in the algal biomass/remnants will be converted to pyrroles, indoles, and poly-heteroaromatic compounds that need to be removed to prevent poisoning of the catalysts or nitrogen oxide emissions during combustion. In contrast, the pyrolysis of algal biomass in the presence of zeolite 
causes the biomass to denitrify and deoxygenate and produce aromatic hydrocarbons. The aromatics are high-value chemicals that are responsible for enhancing the octane rating of gasoline. This process opens a new avenue for converting algal biomass directly into fuels and high-value chemicals.

After extraction, the lipids must be converted into simple alkyl esters (biodiesel) through a process known as transesterification during which the viscosity of the lipids will be reduced. During the transesterification process, the lipid reacts with alcohol such as ethanol and methanol in the presence of a catalyst to form esters and glycerol (Kumar et al., 2019). Depending upon the catalysis mechanism, transesterification is classified into chemical-catalyzed reaction, non-catalyzed reaction, or enzymecatalyzed reaction.

Chemical-catalyzed reactions are further classified into heterogeneous and homogeneous reactions. The heterogeneous reaction takes place in the presence of acid or alkali catalyst in solid state, and examples for these catalysts are calciumbased metal oxides and sulfated zirconia (Aransiola et al., 2014). Similarly, the homogeneous reaction takes place in the presence of acid or alkali catalyst in liquid state, and examples for such catalysts are hydrochloric acid, sulfuric acid, sodium hydroxide, and potassium hydroxide (Ong et al., 2014). Though the alkalibased transesterification process takes place quickly, it is not viable in case of feedstocks with higher FFAs due to the formation of soap. On the other hand, disadvantages with acid-based transesterification are longer incubation time, corrosive nature, higher energy consumption, glycerol purification costs, etc.

Non-catalyzed transesterification reaction occurs quickly under supercritical conditions, and the product obtained through the process can be separated easily without generation of waste. The demerits of the process are the requirement of high temperature $\left(250-400^{\circ} \mathrm{C}\right)$ and pressure $(10-30 \mathrm{MPa})$, which is very expensive (Stamenković et al., 2011). To address the problems related to the chemical-catalyzed and non-catalyzed reactions, the researchers explored enzymatic transesterification that operates under mild conditions and has high substrate specificity (Christopher et al., 2014). Shimada et al. (2002) reported $98.5 \%$ of FAME conversion by enzymatic transesterification (immobilized lipase from Candida antarctica) from docosahexanoic acid.

\section{Physicochemical Properties of Lignocellulosic-Based Oleaginous Fatty Acid Methyl Esters}

Fatty acid methyl esters suitability is mainly determined through the produced FAME's physicochemical properties, which have to be within the permissible limits of the standards (ASTM D3751, EN14214) and petrodiesel comparative studies (Kumari et al., 2009; Garlapati et al., 2021). Moreover, FAME's properties also depend on the fatty acid profiles of utilized oleaginous oils. The fatty acid profiles of oleaginous oils also resemble the edible and non-edible oils in prominent fatty acid presence such as $\mathrm{C}_{16: 0}, \mathrm{C}_{18: 0}, \mathrm{C}_{18: 1}$, and $\mathrm{C}_{18: 2}$ (Patel et al., 2017). The presence of unsaturated fatty acids is the ideal constituent for FAME's production, up to certain tolerable polyunsaturated fatty acid presence limits. The unsaturation of produced FAMEs drawn through the determination of iodine value (IV) and polyunsaturated fatty acids dictate the oxidative stability of produced FAMEs. The formation of soaps through unreacted fatty acids in the produced FAMEs was dictated through the saponification value. The determination of kinematic viscosity will dictate the flow properties of FAMEs in the engine.

The high proportion of saturated fatty acids in FAMEs mitigates auto-oxidation, which eventually enhances the shelf life. In the meantime, unsaturated fatty acids in FAMEs are prone to cold-flow plugging properties (CFPP). Hence, it is recommendable to maintain an optimum ratio of saturated and unsaturated fatty acids in FAMEs (possible through the initial selection of single-cell oils) for better physicochemical properties (oxidative stability, better cold-flow properties) (Meng et al., 2009; Patel et al., 2017). Determination of IV facilitates the estimation of FAME's unsaturated fatty acid content. The IV values of FAMEs need to be within prescribed limits to avoid gum formation through glyceride polymerization on heating (Knothe, 2006; Patel et al., 2016). The enhanced and smooth engine run is feasible with high cetane numbers, which denote better ignition and complete combustion of FAMEs with reduced gaseous and particulate emission profiles.

On the other hand, the high heating value (HHV) of FAMEs is usually on the higher end side, presumably with higher $\mathrm{C} / \mathrm{H}$ and $\mathrm{C} / \mathrm{N}$ ratios (Ramírez-Verduzco et al., 2012). The emissions and combustion problems of FAMEs also related to their high kinematic viscosity $(\mathrm{KV})$, which results in large size of droplets and less combustion efficiency (Patel et al., 2017; Garlapati et al., 2021). The other property of FAMEs, namely, density, also has a detrimental effect on the air-to-fuel ratio and HHV. The KV and density of FAMEs need to be within permissible limits for fruitful engine performance (Hoekman et al., 2012).

The oxidative stability (OS) gives information about the autooxidation potential, which dictates FAME's shelf life, which has to be preferential to be on the higher side. The FAME's OS is usually linear with fatty acid chain length and has inverse behavior with double bonds in cis configuration (Hoekman et al., 2012; Stansell et al., 2012). Overall, the presence of unsaturation, soaps, particulate contaminants, and sulfur can influence the cetane number, HHV, and cold filter plugging point, which have to be determined to propose the suitability of the oleaginous FAMEs as transportation fuels (Patel et al., 2016). The fuel properties of oleaginous FAMEs determined by different researchers have been summarized in Table 6.

\section{METABOLIC ENGINEERING APPROACHES FOR ENHANCED LIPID SYNTHESIS AND BIOREFINERY PRODUCTS}

Oleaginous microorganisms are gaining great interest for their ability in the production of target compounds using varied carbon sources (Kumar et al., 2020e). However, to exploit these OMs with high lipid productivity and yield at industrial scale, the strains need to be optimized. Synthetic 
TABLE 6 | Physico-chemical properties of lignocelullose-based oleaginous FAME's.

\begin{tabular}{|c|c|c|c|c|c|c|c|c|c|c|}
\hline $\begin{array}{l}\text { Oleaginous } \\
\text { microbes } \\
\text { (Lignocellulosic } \\
\text { substrate) }\end{array}$ & $\begin{array}{l}\text { Fatty acid } \\
\text { Profile (\%) }\end{array}$ & $\begin{array}{l}\text { Oxidative } \\
\text { stability, at } \\
110^{\circ} \mathrm{C}(\mathrm{h})\end{array}$ & $\begin{array}{l}\text { Kinematic } \\
\text { viscosity } \\
\left(\mathrm{mm}^{2} / \mathrm{s} \text { at }\right. \\
\left.40^{\circ} \mathrm{C}\right)\end{array}$ & $\begin{array}{l}\text { Cold filter } \\
\text { plugging } \\
\text { point } \\
\left(\mathrm{CFPP},{ }^{\circ} \mathrm{C}\right)\end{array}$ & $\begin{array}{l}\text { Density } \\
\left(\mathrm{g} / \mathrm{cm}^{3} \text { at }\right. \\
\left.20^{\circ} \mathrm{C}\right)\end{array}$ & $\begin{array}{l}\text { Saponification } \\
\text { value } \\
\text { (mgKOH) }\end{array}$ & $\begin{array}{l}\text { lodine value } \\
\left.\text { (mg } \mathrm{I}_{2} / 100 \mathrm{~g}\right)\end{array}$ & $\begin{array}{l}\text { Cetane } \\
\text { number }\end{array}$ & $\begin{array}{l}\text { High } \\
\text { heating } \\
\text { value } \\
(\mathrm{MJ} / \mathrm{kg})\end{array}$ & References \\
\hline $\begin{array}{l}\text { Rhodotorula } \\
\text { mucilaginosa } \\
\text { KKUSY14 (UDPH) }\end{array}$ & $\begin{array}{l}C_{16: 0}-19.2 \\
C_{18: 0}-9.5 \\
C_{18: 1}-51.2 \\
C_{18: 2}-\end{array}$ & & 4.85 & 7.62 & 0.873 & & 50.53 & 66.52 & 41.41 & $\begin{array}{l}\text { Siwina and } \\
\text { Leesing, } 2021\end{array}$ \\
\hline $\begin{array}{l}\text { Rhodotorula } \\
\text { mucilaginosa } \\
\text { KKUSY14 (UDPH) }\end{array}$ & $\begin{array}{l}C_{16: 0}-18.2 \\
C_{18: 0}-2.4 \\
C_{18: 1}-65.7 \\
C_{18: 2}-\end{array}$ & & 4.79 & -6.86 & 0.878 & & 59.77 & 61.33 & 40.68 & $\begin{array}{l}\text { Siwina and } \\
\text { Leesing, } 2021\end{array}$ \\
\hline Mucor indicus (CS) & $\begin{array}{l}C_{16: 0}-13.7 \\
C_{18: 0}-53.5 \\
C_{18: 2}-6.1 \\
C_{18: 3}-4.0\end{array}$ & 14.27 & 4.11 & 23.51 & - & - & 70 & 57.7 & - & $\begin{array}{l}\text { Alavijeh et al., } \\
2020\end{array}$ \\
\hline $\begin{array}{l}\text { Rhodotorula } \\
\text { taiwanensis } \\
\text { AM2352 }(\mathrm{CH})\end{array}$ & $\begin{array}{l}C_{16: 0}-24.4 \\
C_{18: 0}-2.9 \\
C_{18: 1}-46.8 \\
C_{18: 2}-6.35\end{array}$ & - & 4.82 & 4.6 & - & - & 81.39 & 58.79 & 39.61 & $\begin{array}{l}\text { Miao et al., } \\
2020\end{array}$ \\
\hline $\begin{array}{l}\text { Cryptococcus } \\
\text { curvatus (WOPH) }\end{array}$ & $\begin{array}{l}C_{16: 0}-3.95 \\
C_{18: 0}-7.07 \\
C_{18: 1}-50.8 \\
C_{18: 2}-4.25\end{array}$ & - & - & -4.13 & 0.92 & 222.09 & 79.06 & 53.09 & 41.61 & Nair et al., 2020 \\
\hline $\begin{array}{l}\text { Bacillus cereus } \\
\text { (MF908505) (PWP) }\end{array}$ & - & - & 4.6 & - & 0.88 & - & 115 & - & - & $\begin{array}{l}\text { Kanakdande } \\
\text { et al., } 2020\end{array}$ \\
\hline $\begin{array}{l}\text { Rhodotorula } \\
\text { pacifica INDKK } \\
\text { (UPSH) }\end{array}$ & $\begin{array}{l}C_{16: 0}-28.8 \\
C_{18: 0}- \\
C_{18: 1}-52.5 \\
C_{18: 2}-12.4 \\
C_{18: 3}-1.37\end{array}$ & & 3.9 & -6.1 & 0.87 & & 86.29 & 53.92 & 38.14 & $\begin{array}{l}\text { Kumar et al., } \\
2020 b\end{array}$ \\
\hline $\begin{array}{l}\text { Rhodotorula } \\
\text { pacifica INDKK } \\
\text { (DPSH) }\end{array}$ & $\begin{array}{l}C_{16: 0}-14.4 \\
C_{18: 0}-6.13 \\
C_{18: 1}-61.9 \\
C_{18: 2}-16.8 \\
C_{18: 3}-1.3\end{array}$ & & 3.7 & -5.97 & 0.84 & & 73.58 & 56.72 & 39.42 & $\begin{array}{l}\text { Kumar et al., } \\
2020 b\end{array}$ \\
\hline $\begin{array}{l}\text { Meyerozyma } \\
\text { guilliermondii (Bag) }\end{array}$ & - & 0 & - & -9 & 0.65 & 167.35 & 15.61 & 75.4 & 29.17 & $\begin{array}{l}\text { Ananthi et al., } \\
2019\end{array}$ \\
\hline $\begin{array}{l}\text { Meyerozyma } \\
\text { guilliermondii }(\mathrm{RH})\end{array}$ & - & 47.4 & - & -9.54 & 0.82 & 225.78 & 39.27 & 61.64 & 36.08 & $\begin{array}{l}\text { Ananthi et al., } \\
2019\end{array}$ \\
\hline $\begin{array}{l}\text { Pichia kudriavzevii } \\
\text { (Bag) }\end{array}$ & - & 0 & - & -16.48 & 0.88 & 472.54 & 0 & 57.85 & 30.41 & $\begin{array}{l}\text { Ananthi et al., } \\
2019\end{array}$ \\
\hline $\begin{array}{l}\text { Pichia kudriavzevii } \\
(\mathrm{RH})\end{array}$ & - & 0 & - & -6.3 & 0.87 & 223.37 & 0 & 70.73 & 39.03 & $\begin{array}{l}\text { Ananthi et al., } \\
2019\end{array}$ \\
\hline $\begin{array}{l}\text { Pichia manshurica } \\
\text { (Bag) }\end{array}$ & - & 0 & & 47.24 & 0.87 & 262.42 & 9.34 & 65 & 37.76 & $\begin{array}{l}\text { Ananthi et al., } \\
2019\end{array}$ \\
\hline $\begin{array}{l}\text { Pichia manshurica } \\
(\mathrm{RH})\end{array}$ & - & 0 & - & -16.48 & 0.79 & 356.38 & 0 & 61.62 & 30.16 & $\begin{array}{l}\text { Ananthi et al., } \\
2019\end{array}$ \\
\hline $\begin{array}{l}\text { Pichia kudriavzevii } \\
\text { (Bag) }\end{array}$ & - & 10.95 & - & 9.88 & 0.56 & 130.99 & 40.95 & 78.75 & 24.8 & $\begin{array}{l}\text { Ananthi et al., } \\
2019\end{array}$ \\
\hline $\begin{array}{l}\text { Pichia kudriavzevii } \\
(\mathrm{RH})\end{array}$ & - & 37.17 & - & -15.63 & 0.84 & 250.34 & 19.42 & 63.73 & 36.39 & $\begin{array}{l}\text { Ananthi et al., } \\
2019\end{array}$ \\
\hline $\begin{array}{l}\text { Candida albicans } \\
\text { (Bag) }\end{array}$ & - & 0 & - & -16.48 & 0.87 & 247.64 & 0 & 68.34 & 38.26 & $\begin{array}{l}\text { Ananthi et al., } \\
2019\end{array}$ \\
\hline $\begin{array}{l}\text { Candida albicans } \\
(\mathrm{RH})\end{array}$ & - & 0 & - & -16.48 & 0.87 & 331.93 & 0 & 62.74 & 35.17 & $\begin{array}{l}\text { Ananthi et al., } \\
2019\end{array}$ \\
\hline $\begin{array}{l}\text { Rhodotorula } \\
\text { mucilaginosa (Bag) }\end{array}$ & - & 22.34 & - & 51.1 & 0.74 & 183.38 & 24.46 & 70.59 & 33.27 & $\begin{array}{l}\text { Ananthi et al., } \\
2019\end{array}$ \\
\hline $\begin{array}{l}\text { Rhodotorula } \\
\text { mucilaginosa }(\mathrm{RH})\end{array}$ & - & 21.31 & - & 0.02 & 0.88 & 331.62 & 12.73 & 59.89 & 35.53 & $\begin{array}{l}\text { Ananthi et al., } \\
2019\end{array}$ \\
\hline
\end{tabular}


TABLE 6 | Continued

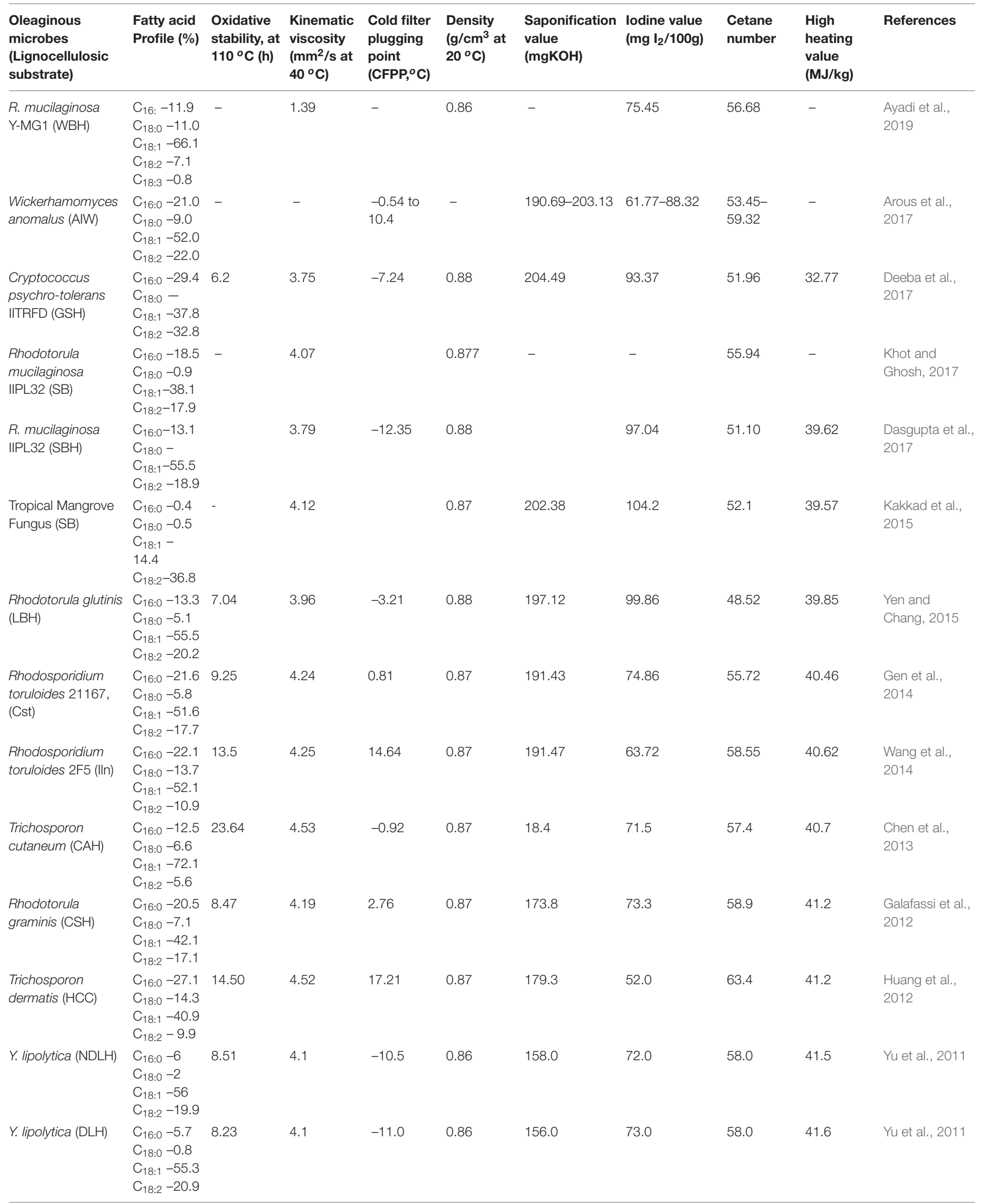


TABLE 6 | Continued

\begin{tabular}{|c|c|c|c|c|c|c|c|c|c|c|}
\hline $\begin{array}{l}\text { Oleaginous } \\
\text { microbes } \\
\text { (Lignocellulosic } \\
\text { substrate) }\end{array}$ & $\begin{array}{l}\text { Fatty acid } \\
\text { Profile (\%) }\end{array}$ & $\begin{array}{l}\text { Oxidative } \\
\text { stability, at } \\
110^{\circ} \mathrm{C}(\mathrm{h})\end{array}$ & $\begin{array}{l}\text { Kinematic } \\
\text { viscosity } \\
\left(\mathrm{mm}^{2} / \mathrm{s} \text { at }\right. \\
\left.40^{\circ} \mathrm{C}\right)\end{array}$ & $\begin{array}{l}\text { Cold filter } \\
\text { plugging } \\
\text { point } \\
\left(\mathrm{CFPP},{ }^{\circ} \mathrm{C}\right)\end{array}$ & $\begin{array}{l}\text { Density } \\
\left(\mathrm{g} / \mathrm{cm}^{3} \text { at }\right. \\
\left.20^{\circ} \mathrm{C}\right)\end{array}$ & $\begin{array}{l}\text { Saponification } \\
\text { value } \\
\text { (mgKOH) }\end{array}$ & $\begin{array}{l}\text { lodine value } \\
\left(\mathrm{mg} \mathrm{I}_{2} / 100 \mathrm{~g}\right)\end{array}$ & $\begin{array}{l}\text { Cetane } \\
\text { number }\end{array}$ & $\begin{array}{l}\text { High } \\
\text { heating } \\
\text { value } \\
(\mathrm{MJ} / \mathrm{kg})\end{array}$ & References \\
\hline R. glutinis (NDLH) & $\begin{array}{l}C_{16: 0}-23.5 \\
C_{18: 0}-9.0 \\
C_{18: 1}-43.4 \\
C_{18: 2}-15.4\end{array}$ & 10.24 & 4.25 & 5 & 0.861 & 177 & 60 & 59 & 41.0 & Yu et al., 2011 \\
\hline Y. lipolytica (DLH) & $\begin{array}{l}C_{16: 0}-5.7 \\
C_{18: 0}-0.8 \\
C_{18: 1}-55.3 \\
C_{18: 2}-20.9\end{array}$ & 8.52 & 4.52 & -13.16 & 0.87 & 153.17 & 82.43 & 60 & 41.95 & Yu et al., 2011 \\
\hline L. starkeyi (DLH) & $\begin{array}{l}C_{16: 0}-37.1 \\
C_{18: 0}-5.5 \\
C_{18: 1}-45.1 \\
C_{18: 2}-4.9\end{array}$ & 26.65 & 4.53 & 5.59 & 0.87 & 181.94 & 47.16 & 64.27 & 41.26 & Yu et al., 2011 \\
\hline
\end{tabular}

DLH, detoxified liquid wheat straw hydrolysate; NDLH, non-detoxified liquid wheat straw hydrolysate; LBH, lignocellulosic biomass hydrolysate; SB, sugarcane baggase; HCC, hydrolysates of corncobs; CSH, corn stover hydrolysate; CAH, corncob acid hydrolysate; SBH, sugarcane bagasse hydrolysate; UDPH, undetoxified durian peel hydrolysate; CS, corn stover; $\mathrm{CH}$, corncob hydrolysate; WOPH, waste office paper hydrolysate; PWP, pomegranate waste-peel; UPSH, undetoxified pongamia shell hydrolysate; DPSH, detoxified pongamia shell hydrolysate; Bag, baggase; RH, rice husk; WBH, wheat bran hydrolysate; AIW, agro-Industrial wastewaters; GSH, groundnut shell hydrolysate; CST, cassava starch; Inn, inulin.

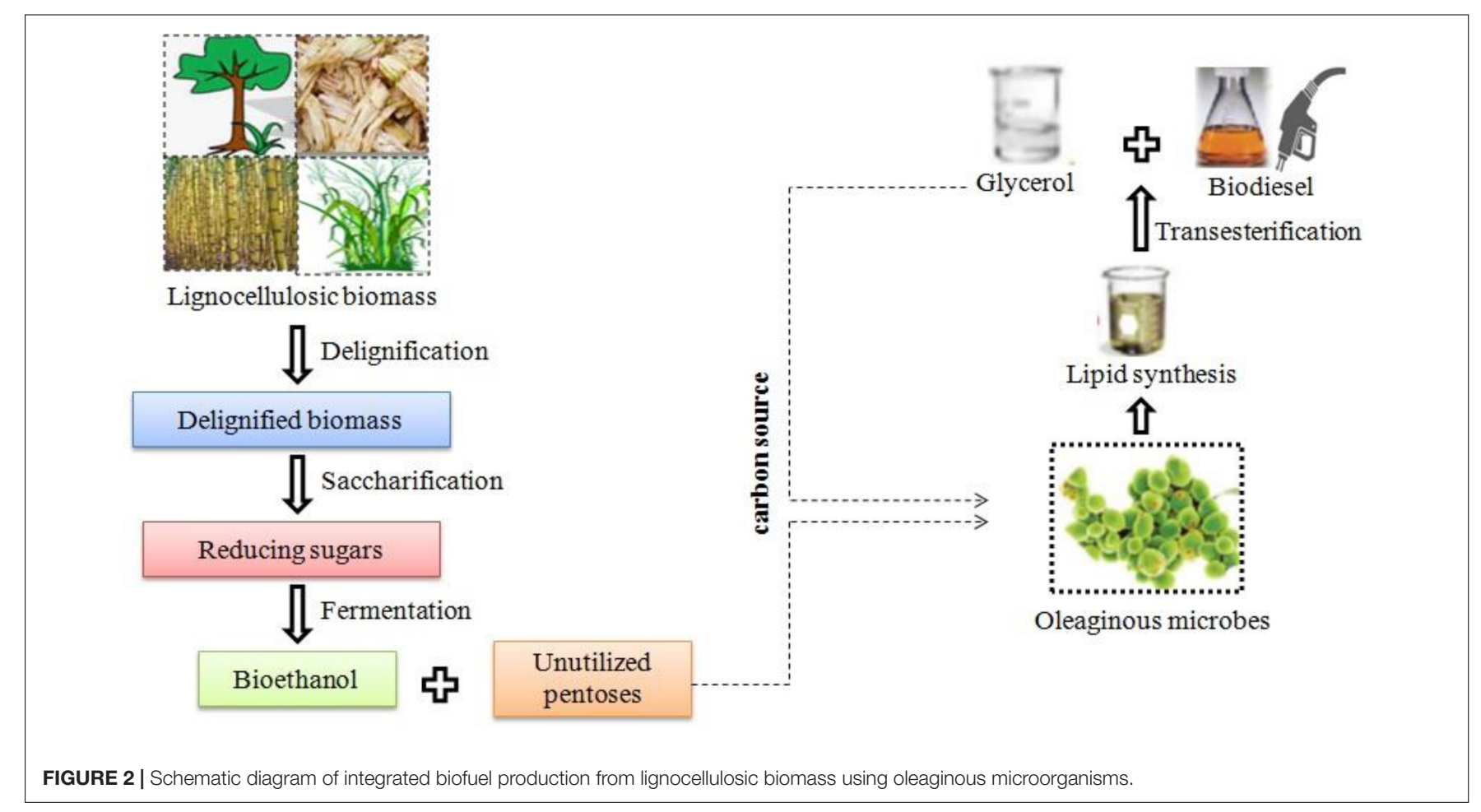


biology, ME, genome editing, and genetic elements are being advanced; combining these essential components, OMs could be modified for biofuel production, industrial chemicals, and biorefinery. Strategies pertinent to $\mathrm{ME}$ of $\mathrm{OMs}$ are composed of (1) production of fatty acid-derived compounds [FAMEs, TAGs, fatty alcohols (FALs), FFAs]; (2) acetyl CoAderived products [terpenoids, poly-3-hydroxybutyrate (PHB)]; (3) production of industrial compounds like citric acid, succinic acid, $\alpha$-ketoglutarate, itaconic acid, and erythritol; (4) utilization of low-cost substrates such as LCB, starch, inulin, molasses, and glycerol (Levering et al., 2015).

All strategies are aimed for the development of viable technologies for either biofuel production or biorefinery compounds (Shi and Zhao, 2017). The last strategy has targeted to utilize the feedstocks efficiently in the fermentation process. As many strains are incapable of growing in inexpensive carbon sources, OMs need to engineer for efficient utilization of inexpensive carbon sources. Some efforts are being laid to utilize cellobiose, xylose from hemicelluloses, starch, molasses, inulin, and glycerol, which is a by-product of biodiesel industry. Similarly, model systems with targeted industrial chemicals would lead to biorefinery development. Although ME strategies are showing promising results, $\mathrm{ME}$ of oleaginous yeasts and microalgae is in its infancy. A plausible reason is low flux toward synthesis of target compounds due to low activity of heterologous pathways. Hence, future studies should target engineering of novel enzymes with stability and higher activity, specificity, optimization of heterologous and homologous pathways, and maintenance of balance between growth and lipid productivity (Tai and Stephanopoulos, 2013; Blazeck et al., 2014).

Synthetic biology approaches are promising and facilitate biological engineering of strain cycle through Design-Build-TestLean (DBTL) approach. Recent advances in synthetic biology research have facilitated developing new tools to perform genetic engineering in nonconventional yeasts such as Yarrowia lipolytica and R. toruloides (Bredeweg et al., 2017; Park et al., 2018; Xiong et al., 2021). Cloning of essential genetic elements such as constitutive, inducible, targeted, and repressible promoters is being carried out in $R$. toruloides and Y. lipolytica (Nora et al., 2019). Besides, engineering of tandem copies pertinent to upstream activation sequences (UASs) has been modified to strengthen the hybrid promoter for higher expressions in Y. lipolytica (Blazeck et al., 2011; Xiong and Chen, 2020). Genome editing mediated by clustered regularly interspersed short palindromic repeats (CRISPR) along with Cas protein has been studied in $Y$. lipolytica and $R$. toruloides, which can be optimized to improve the efficiency of lipid accumulation by adopting multiplex genome engineering with low off-target effects (Jiao et al., 2019; Otoupal et al., 2019; Schultz et al., 2019; Abdel-Mawgoud and Stephanopoulos, 2020; Yang et al., 2020). In addition to these approaches, Koh et al. (2014) developed Creloxp recombination system for marker-free transformation in $R$. toruloides and Y. lipolytica that could enhance the homologous frequency with the disruption of Ku70 encoding gene. Besides, to improve the stability and yield of oleaginous engineered strains, bacterial transcriptional factors coupled with genetically encoded biosensors pertinent to malonyl-CoA and flavonoid pathway have been recruited in Y. lipolytica (Lv et al., 2020). These studies imply that the tools for enhanced genetic engineering for increased lipid accumulation coupled with biorefinery in OMs could be a promising approach for the development of commercially viable technologies.

\section{FUTURE PROSPECTS FOR INTEGRATION OF BIOFUEL PRODUCTION FROM LIGNOCELLULOSIC BIOMASS}

The development of a viable process is an essential feature of a mature technology that can be done by adopting a circular economy approach. Unlike linear economy, circular economy generates value in at least four domains: (1) raw substance reutilization for biofuels with increased value; (2) enhances mutual economic growth through the development of liquid markets, where the products are exchanged among users; (3) integration of bioprocesses with zero waste creation; and (4) reusable potential of products that are applicable for varied purposes (Nogué et al., 2018; Chandel et al., 2020). In the bioethanol industry, conversion of LCB to bioethanol production has been done, but in terms of economic viability, several developed technologies are still in the infancy stage (Chintagunta et al., 2016; Jacob et al., 2016). Economic viability of the process could be ascertained through circular economy, where the byproduct or waste can be reused that ultimately reduces the cost involved in the process (Amore et al., 2016; Chandel et al., 2020). Here, we are proposing a scheme of circular economy for biofuel production from LCB using OMs.

In bioethanol production, delignification, saccharification, and fermentation are the major steps involved in the process. After the delignification process, the lignin degraded particularly using enzymatic means can be used as antioxidants, glucose biosensor, reusable adsorbent, silver nanoparticles, electric double-layer capacitor, etc. (Kumar et al., 2020e). In the fermentation process, pentoses remain mostly unutilized. Hence, supplementing these pentoses as carbon source to OMs for lipid production could be a viable option. Furthermore, these lipids can be converted to FAMEs, i.e., biodiesel and glycerol, where the latter can be used as a carbon source for biodiesel production (Figure 2). The biomass generated after lipid extraction can be used for nutrient enrichment along with cyanobacteria and can be used as biomanure and biofertilizer, respectively. Therefore, integration of processes could lead to synthesis of biofuels and industrial chemicals with zero-waste concept.

\section{CONCLUSION}

Biofuels play an important role in enabling society toward sustainable development. Development of economic biofuels particularly biodiesel can be achieved using LCB and OM owing to their capacity of utilizing inexpensive feedstocks for higher lipid accumulation. Furthermore, integration of biofuel 
process such as bioethanol and biodiesel production has great scope for the development of economic viable technologies that ultimately edify society. Economic viability of the process could be ascertained through life cycle assessment and technoeconomic analysis studies.

\section{AUTHOR CONTRIBUTIONS}

AC reviewed the literature, drafted the manuscript, and drew the figures. GZ reviewed the literature and drafted the manuscript. MK reviewed the literature and compiled and drafted the manuscript. SK conceived the idea and analyzed and drafted the manuscript. VG drafted the manuscript and compiled the information. PP compiled the information and drafted the manuscript. NK edited the manuscript. AC meticulously analyzed, compiled, and

\section{REFERENCES}

Abdel-Mawgoud, A., and Stephanopoulos, G. (2020). Improving CRISPR/Cas9mediated genome editing efficiency in Yarrowia lipolytica using direct tRNA-sgRNA fusions. Metab. Eng. 62, 106-115. doi: 10.1016/j.ymben.2020.0 7.008

Adachi, D., Hama, S., and Numata, T. (2011). Development of an Aspergillus oryzae whole-cell biocatalyst co-expressing triglyceride and partial glyceride lipases for biodiesel production. Bioresour. Technol. 102, 6723-6729. doi: 10.1016/j. biortech.2011.03.066

Adewale, P., Dumont, M.-J., and Ngadi, M. (2015). Recent trends of biodiesel production from animal fat wastes and associated production techniques. Renew. Sust. Energy Rev. 45, 574-588. doi: 10.1016/j.rser.2015.02.039

Alavijeh, R. S., Karimi, K., and Van den Berg, C. (2020). An integrated and optimized process for cleaner production of ethanol and biodiesel from corn stover by Mucor indicus. J. Clean. Prod. 249:119321. doi: 10.1016/j.jclepro.2019. 119321

Alizadeh, H., Teymouri, F., Gilbert, T. I., and Dale, B. E. (2005). Pretreatment of switchgrass by ammonia fiber explosion (AFEX). Appl. Biochem. Biotechnol. 124:1133. doi: 10.1385/ABAB:124:1-3:1133

Alvarez, H. M., and Steinbüchel, A. (2002). Triacylglycerols in prokaryotic microorganisms. Appl. Microbiol. Biol. 60, 367-376. doi: 10.1007/s00253-002$1135-0$

Amore, A., Ciesielski, P., Lin, C. Y., Salvachúa, D., and Nogué, V. S. (2016). Development of lignocellulosic biorefinery technologies: recent advances and current challenges. Aust. J. Chem. 69, 1201-1218. doi: 10.1071/CH16022

Ananthi, V., Prakash, G. S., Chang, S. W., Ravindran, B., Nguyen, D. D., Vo, D. N., et al. (2019). Enhanced microbial biodiesel production from lignocellulosic hydrolysates using yeast isolates. Fuel 256:115932. doi: 10.1016/j.fuel.2019. 115932

Aransiola, E. F., Ojumu, T. V., and Oyekola, O. O. (2014). A review of current technology for biodiesel production: state of the art. Biomass Bioenergy 61, 276-297. doi: 10.1016/j.biombioe.2013.11.014

Aratboni, H. A., Rafiei, N., Garcia-Granados, R., Alemzadeh, A., and MoronesRamírez, J. R. (2019). Biomass and lipid induction strategies in microalgae for biofuel production and other applications. Microb. Cell Fact. 18, 1-17. doi: 10.1186/s12934-019-1228-4

Arous, F., Atitallah, I. B., Nasri, M., and Mechichi, T. (2017). A sustainable use of low-cost raw substrates for biodiesel production by the oleaginous yeast Wickerhamomyces anomalus. 3 Biotech 7:268. doi: 10.1007/s13205-0170903-6

Atabani, A. E., Silitonga, A. S., Badruddin, I. A., Mahila, T. M. I., Masjuki, H. H., and Mekhile, S. (2012). A comprehensive review on biodiesel as an alternative energy resource and its characteristics. Renew. Sust. Energy Rev. 16, 2070-2093. doi: 10.1016/j.rser.2012.01.003 edited the manuscript. JS-G compiled the literature and edited the manuscript.

\section{FUNDING}

This work was supported by the Proyecto de Unidades Ejecutoras CERZOS (CONICET) and by Xunta de Galicia, ED431C2018/42-GRC.

\section{ACKNOWLEDGMENTS}

The authors are grateful to the directors of ICAR-Indian Institute of Seed Science, Mau, India, and ICAR-Directorate of Floricultural Research, Pune, India, for smooth facilitation in executing the work. The authors are grateful to Management, VFSTR, India, for extending their kind support.

Athenaki, M., Gardeli, C., Diamantopoulou, P., Tchakouteu, S. S., Sarris, D., Philippoussis, A., et al. (2018). Lipids from yeasts and fungi: physiology, production and analytical considerations. J. Appl. Microbiol. 124, 336-367. doi: 10.1111/jam.13633

Ayadi, I., Belghith, H., Gargouri, A., and Guerfali, M. (2019). Utilization of wheat bran acid hydrolysate by Rhodotorula mucilaginosa Y-MG1 for microbial lipid production as feedstock for biodiesel synthesis. BioMed Res. Int. 2019:3213521. doi: $10.1155 / 2019 / 3213521$

Balat, M. (2011). Potential alternatives to edible oils for biodiesel production- a review of current work. Energy Convers. Manage. 52, 1479-1492. doi: 10.1016/j. enconman.2010.10.011

Banerjee, R., Chintagunta, A. D., and Ray, S. (2017). A cleaner and eco-friendly bioprocess for enhancing reducing sugar production from pineapple leaf waste. J. Clean. Prod. 149, 387-395. doi: 10.1016/j.jclepro.2017.02.088

Banerjee, R., Chintagunta, A. D., and Ray, S. (2019a). Laccase mediated delignification of pineapple leaf waste: an eco-friendly sustainable attempt towards valorization. BMC Chem. 13:58. doi: 10.1186/s13065-019-0 576-9

Banerjee, R., Kumar, S. P. J., Mehendale, N., Sevda, S., and Garlapati, V. K. (2019b). Intervention of microfluidics in biofuel and bioenergy sectors: technological considerations and future prospects. Renew. Sustain. Energy Rev. 101, 548-558. doi: 10.1016/j.rser.2018.11.040

Barakat, A., Monlau, F., Solhy, A., and Carrere, H. (2015). Mechanical dissociation and fragmentation of lignocellulosic biomass: effect of initial moisture, biochemical and structural proprieties on energy requirement. Appl. Energy 142, 240-246. doi: 10.1016/j.apenergy.2014.12.076

Baruah, J., Nath, B. K., Sharma, R., Kumar, S., Deka, R. C., Baruah, D. C., et al. (2018). Recent trends in the pretreatment of lignocellulosic biomass for value-added products. Front. Energy Res. 6:141. doi: 10.3389/fenrg.2018.00141

Bhuvaneshwari, S., Hettiarachchi, H., and Meegoda, J. N. (2019). Crop residue burning in India: policy challenges and potential solutions. Int. J. Environ. Res. Public Health 16:832. doi: 10.3390/ijerph16050832

Blazeck, J., Hill, A., Liu, L., Knight, R., Miller, J., and Pan, A. (2014). Harnessing Yarrowia lipolytica lipogenesis to create a platform for lipid and biofuel production. Nat. Commun. 5:3131. doi: 10.1038/ncomms4131

Blazeck, J., Liu, L., Redden, H., and Alper, H. (2011). Tuning gene expression in Yarrowia lipolytica by a hybrid promoter approach. Appl. Environ. Microbiol. 77, 7905-7914. doi: 10.1128/AEM.05763-11

Bredeweg, E. L., Pomraning, K. R., Dai, Z., Nielsen, J., Kerkhoven, E. J., and Baker, S. E. (2017). A molecular genetic toolbox for Yarrowia lipolytica. Biotechnol. Biofuels 10:2. doi: 10.1186/s13068-017-0731-2

Chaiyaso, T., Manowattana, A., Techapun, C., and Watanabe, M. (2019). Efficient bioconversion of enzymatic corncob hydrolysate into biomass and lipids by oleaginous yeast Rhodosporidium paludigenum KM281510. Prep. Biochem. Biotechnol. 49, 545-556. doi: 10.1080/10826068.2019.1591985 
Chan, L. G., Dias, F. F. G., Saarni, A., Cohen, J., Block, D., Taha, A. Y., et al. (2020). Scaling up the bioconversion of cheese whey permeate into fungal oil by Mucor circinelloides. J. Am. Oil Chem. Soc. 97, 703-716. doi: 10.1002/aocs.12372

Chandel, A. K., Garlapati, V. K., Kumar, S. P. J., Hans, M., Singh, A. K., and Kumar, S. (2020). The role of renewable chemicals and biofuels in building a bioeconomy. Biofuels Bioprod. Biorefin. 14, 830-844. doi: 10.1002/bbb.2104

Chandel, A. K., Garlapati, V. K., Singh, A. K., Antunes, F. A. F., and da Silva, S. S. (2018). The path forward for lignocellulose biorefineries: bottlenecks, solutions, and perspective on commercialization. Bioresour. Technol. 264, 370-381. doi: 10.1016/j.biortech.2018.06.004

Chang, Y. H., Chang, K. S., Lee, C. F., Hsu, C. L., Huang, C. W., and Jang, H. D. (2015). Microbial lipid production by oleaginous yeast Cryptococcus sp. in the batch cultures using corncob hydrolysate as carbon source. Biomass Bioenergy 72, 95-103. doi: 10.1016/j.biombioe.2014.11.012

Chaturvedi, V., and Verma, P. (2013). An overview of key pretreatment processes employed for bioconversion of lignocellulosic biomass into biofuels and value added products. 3 Biotech 3, 415-431. doi: 10.1007/s13205-013-0167-8

Cheirsilp, B., Thawechai, T., and Prasertsan, P. (2017). Immobilized oleaginous microalgae for production of lipid and phytoremediation of secondary effluent from palm oil mill in fluidized bed photobioreactor. Bioresour. Technol. 241, 787-794. doi: 10.1016/j.biortech.2017.06.016

Chen, B. Y., Chen, S. W., and Wang, H. T. (2012). Use of different alkaline pretreatments and enzyme models to improve low-cost cellulosic biomass conversion. Biomass Bioenergy 39, 182-191. doi: 10.1016/j.biombioe.2012. 01.012

Chen, X. F., Huang, C., Yang, X. Y., Xiong, L., Chen, X. D., and Ma, L. L. (2013). Evaluating the effect of medium composition and fermentation condition on the microbial oil production by Trichosporon cutaneum on corn cob acid hydrolysate. Bioresour. Technol. 143, 18-24. doi: 10.1016/j.biortech.2013.05.102

Chen, X., Li, Z., Zhang, X., Hu, F., Ryu, D. D. Y., and Bao, J. (2009). Screening of oleaginous yeast strains tolerant to lignocellulose degradation compounds. Appl. Biochem. Biotechnol. 159, 591-604. doi: 10.1007/s12010-008-8491-x

Cherubini, F., and Strømman, A. H. (2011). Chemicals from lignocellulosic biomass: opportunities, perspectives, and potential of biorefinery systems. Biofuels Bioprod. Biorefin. 5, 548-561. doi: 10.1002/bbb.297

Chintagunta, A. D., Jacob, S., and Banerjee, R. (2016). Integrated bioethanol and biomanure production from potato waste. Waste Manage. 49, 320-325. doi: 10.1016/j.wasman.2015.08.010

Chintagunta, A. D., Kumar, A., Jeevan Kumar, S. P., and Verma, M. L. (2020). "Contribution of metallic nanomaterials in algal biofuel production," in Metal and Metal Oxides for Energy and Electronics. Environmental Chemistry for a Sustainable World, Vol. 55, eds S. Rajendran, J. Qin, F. Gracia, and E. Lichtfouse (Cham: Springer), 331-353. doi: 10.1007/978-3-030-53065-5_9

Chintagunta, A. D., Ray, S., and Banerjee, R. (2017). An integrated bioprocess for bioethanol and biomanure production from pineapple leaf waste. J. Clean. Prod. 165, 1508-1516. doi: 10.1016/j.jclepro.2017.07.179

Chisti, Y. (2007). Biodiesel from microalgae. Bitechnol. Adv. 25, 294-306. doi: 10.1016/j.biotechadv.2007.02.001

Cho, H. U., and Park, J. M. (2018). Biodiesel production by various oleaginous microorganisms from organic wastes. Bioresour. Technol. 256, 502-508. doi: 10.1016/j.biortech.2018.02.010

Christopher, L. P., Kumar, H., and Zambare, V. P. (2014). Enzymatic biodiesel: challenges and opportunities. Appl. Energy 119, 497-520. doi: 10.1016/j. apenergy.2014.01.017

Dasgupta, D., Sharma, T., Bhatt, A., Bandhu, S., and Ghosh, D. (2017). Cultivation of oleaginous yeast Rhodotorula mucilaginosa IIPL32 in split column airlift reactor and its influence on fuel properties. Biocatal. Agric. Biotechnol. 10, 308-316. doi: 10.1016/j.bcab.2017.04.002

Deeba, F., Pruthi, V., and Negi, Y. S. (2016). Converting paper mill sludge into neutral lipids by oleaginous yeast Cryptococcus vishniaccii for biodiesel production. Bioresour. Technol. 213, 96-102. doi: 10.1016/j.biortech.2016.0 2.105

Deeba, F., Pruthi, V., and Negi, Y. S. (2017). Fostering triacylglycerol accumulation in novel oleaginous yeast Cryptococcus psychrotolerans IITRFD utilizing groundnut shell for improved biodiesel production. Bioresour. Technol. 242, 113-120. doi: 10.1016/j.biortech.2017.04.001

Demirbas, A. (2009a). Progress and recent trends in biodiesel fuels. Energy Convers. Manag. 50, 14-34. doi: 10.1016/j.enconman.2008.09.001
Demirbas, A. (2009b). Production of biodiesel fuels from linseed oil using methanol and ethanol in non-catalytic SCF conditions. Biomass Bioenergy 33, 113-118. doi: 10.1016/j.biombioe.2008.04.018

Demirbas, A., Bafail, A., Ahmad, W., and Sheikh, M. (2016). Biodiesel production from non-edible plant oils. Energy Explor. Exploit. 34, 290-318. doi: 10.1177/ 0144598716630166

Dey, P., Banerjee, J., and Maiti, M. K. (2011). Comparative lipid profiling of two endophytic fungal isolates-Colletotrichumsp. and Alternaria sp. having potential utilities as biodiesel feedstock. Bioresour. Technol. 102, 5815-5823. doi: 10.1016/j.biortech.2011.02.064

Dong, T., Knoshaug, E. P., Pienkos, P. T., and Laurens, L. M. (2016). Lipid recovery from wet oleaginous microbial biomass for biofuel production: a critical review. Appl. Energy 177, 879-895. doi: 10.1016/j.apenergy.2016.06.002

Dorado, M. P. (2008). "Raw materials to produce low-cost biodiesel," in Biofuels Refining and Performance, ed. A. Nag (New York, NY: McGraw-Hill press), 107-147.

Dorado, M. P., Cruz, F., Palomar, J. M., and Lopez, F. J. (2006). An approach to the economics of two vegetable oil-based biofuels in Spain. Renew. Energy 31, 1231-1237. doi: 10.1016/j.renene.2005.06.010

Economou, C. N., Aggelis, G., Pavlou, S., and Vayenas, D. V. (2011). Single cell oil production from rice hulls hydrolysate. Bioresour. Technol. 102, 9737-9742. doi: 10.1016/j.biortech.2011.08.025

Economou, C. N., Makri, A., Aggelis, G., Pavlou, S., and Vayenas, D. V. (2012). Semi-solid state fermentation of sweet sorghum for the biotechnological production of single cell oil. Bioresour. Technol. 101, 1385-1388. doi: 10.1016/j. biortech.2009.09.028

Eggeling, L., and Sahm, H. (1980). Degradation of coniferyl alcohol and other lignin-related aromatic compounds by Nocardia sp. DSM 1069. Arch. Microbiol. 126, 141-148. doi: 10.1007/BF00511219

El-Sheekh, M. M., Bedaiwy, M. Y., Osman, M. E., and Ismail, M. M. (2012). Mixotrophic and heterotrophic growth of some microalgae using extract of fungal-treated wheat bran. Int. J. Rec. Org. Waste Agric. 1, 121-129. doi: 10. 1186/2251-7715-1-12

Fabiszewska, A., Misiukiewicz-Stępień, P., Paplińska-Goryca, M., Zieniuk, B., and Białecka-Florjańczyk, E. (2019). An insight into storage lipid synthesis by Yarrowia lipolytica Yeast relating to lipid and sugar substrates metabolism. Biomolecules 9:685. doi: 10.3390/biom9110685

Fakas, S., Papanikolaou, S., Komaitis, M., and Aggelis, G. (2008). Organic nitrogen of tomato waste hydrolysate enhances glucose uptake and lipid accumulation in Cunninghamella echinulata. J. Appl. Microbiol. 105, 1062-1070. doi: 10.1111/j. 1365-2672.2008.03839.x

Fonseca, J. M., Teleken, J. G., Almeida, V. C., and da Silva, C. (2019). Biodiesel from waste frying oil: methods of production and purification. Energy Convers. Manag. 184, 205-218. doi: 10.1016/j.enconman.2019. 01.061

Fu, C., Mielenz, J. R., Xiao, X., Ge, Y., Hamilton, C. Y., Rodriguez, M., et al. (2011). Genetic manipulation of lignin reduces recalcitrance and improves ethanol production from switchgrass. Proc. Natl. Acad. Sci. U.S.A. 108, 3803-3808. doi: $10.1073 /$ pnas. 1100310108

Galafassi, S., Cucchetti, D., Pizza, F., Franzosi, G., Bianchi, D., and Compagno, C. (2012). Bioresource technology lipid production for second generation biodiesel by the oleaginous yeast Rhodotorula graminis. Bioresour. Technol. 111, 398-403. doi: 10.1016/j.biortech.2012.02.004

Galbe, M., and Zacchi, G. (2002). A review of the production of ethanol from softwood. Appl. Microbiol. Biotechnol. 59, 618-628. doi: 10.1007/s00253-0021058-9

Gao, Q., Cui, Z., Zhang, J., and Bao, J. (2014). Lipid fermentation of corncob residues hydrolysate by oleaginous yeast Trichosporoncutaneum. Bioresour. Technol. 152, 552-556. doi: 10.1016/j.biortech.2013.11.044

Garlapati, V. K., Mohapatra, S. B., Mohanty, R. C., and Das, P. (2021). Transesterified Olax scandens oil as a bio-additive: production and diesel engine performance studies. Tribol. Int. 153:106653. doi: 10.1016/j.triboint. 2020.106653

Gen, Q., Wang, Q., and Chi, Z. M. (2014). Direct conversion of cassava starch into single cell oil by co-cultures of the oleaginous yeast Rhodosporidium toruloides and immobilized amylases-producing yeast Saccharomycopsis fibuligera. Renew. Energy 62, 522-526. doi: 10.1016/j.renene.2013. 08.016 
Goswami, L., Namboodiri, M. M. T., Kumar, R. V., Pakshirajan, K., and Pugazhenthi, G. (2017). Biodiesel production potential of oleaginous Rhodococcus opacus grown on biomass gasification wastewater. Renew. Energy 105, 400-406. doi: 10.1016/j.renene.2016.12.044

Gouda, M., Omar, S., and Aouad, L. (2008). Singlecell oil production by Gordonia sp. DG using agro-industrial wastes. World J. Microbiol. Biotechnol. 24, 17031711. doi: $10.1007 / \mathrm{s} 11274-008-9664-\mathrm{z}$

Grous, W. R., Converse, A. O., and Grethlein, H. E. (1986). Effect of steam explosion pretreatment on pore size and enzymatic hydrolysis of poplar. Enzyme Microb. Technol. 8, 274-280. doi: 10.1016/0141-0229(86)90021-9

Gujjala, L. K. S., Kumar, S. P. J., Talukdar, B., Dash, A., Kumar, S., Sherpa, K. C. H., et al. (2017). Biodiesel from oleaginous microbes: opportunities and challenges. Biofuels 10, 1-15. doi: 10.1080/17597269.2017.14 02587

Haas, M. J., McAloon, A. J., Yee, W. C., and Foglia, T. A. (2006). A process model to estimate biodiesel production costs. Bioresour. Technol. 6, 671-678. doi: 10.1016/j.biortech.2005.03.039

Haghighi, M. S., Hossein, G. A., Tabatabaei, M., Salehi, J. G., Najafi, G. H., Gholami, M., et al. (2013). Lignocellulosic biomass to bioethanol, a comprehensive review with a focus on pretreatment. Renew. Sustain. Energy Rev. 27, 77-93. doi: 10.1016/j.rser.2013.06.033

Hajjaria, M., Tabatabaeia, M., Aghbashlo, M., and Ghanavatia, H. (2017). A review on the prospects of sustainable biodiesel production: a global scenario with an emphasis on waste-oil biodiesel utilization. Renew. Sustain. Energy Rev. 72, 445-464. doi: 10.1016/j.rser.2017.01.034

Himmel, M. E., Ding, S. Y., Johnson, D. K., Adney, W. S., Nimlos, M. R., Brady, J. W., et al. (2007). Biomass recalcitrance: engineering plants and enzymes for biofuels production. Science 315, 804-807. doi: 10.1126/science.1137016

Hoekman, S. K., Broch, A., Robbins, C., Ceniceros, E., and Natarajan, M. (2012). Review of bio- diesel composition, properties, and specifications. Renew. Sustain. Energy Rev. 16, 143-169. doi: 10.1016/j.rser.2011.07.143

Hossain, A. K., and Badr, O. (2007). Prospects of renewable energy utilisation for electricity generation in Bangladesh. Renew. Sustain. Energy Rev. 11, 1617-1649. doi: 10.1016/j.rser.2005.12.010

Huang, C., Chen, X. F., Xiong, L., Chen, X., and Ma, L. L. (2012). Oil production by the yeast Trichosporon dermatis cultured in enzymatic hydrolysates of corncobs. Bioresour. Technol. 110, 711-714. doi: 10.1016/j.biortech.2012.01.077

Huang, C., Chen, X. F., Yang, L., Xiong, X. Q., Lin, J., and Yang, J. (2014). Bioconversion of corncob acid hydrolysate into microbial oil by the oleaginous yeast Lipomycesstarkeyi. Appl. Biochem. Biotechnol. 172, 2197-2204.

Huang, C., Zong, M., Wu, H., and Liu, Q. (2009). Microbial oil production from rice straw hydrolysate by Trichosporon fermentans. Bioresour. Technol. 100, 4535-4538. doi: 10.1016/j.biortech.2009.04.022

Huber, G. W. (2008). Breaking the Chemical and Engineering Barriers to Lignocellulosic Biofuels: Next Generation Hydrocarbon Biorefineries. Washington, DC: National Science Foundation, Chemical, Bioengineering, Environmental and Transport Systems Division, 180.

Hui, L., Wan, C., Hai-tao, D., Xue-jiao, C., Qi-fa, Z., and Yu-hua, Z. (2010). Direct microbial conversion of wheat straw into lipid by a cellulolytic fungus of Aspergillus oryzae A-4 in solid-state fermentation. Bioresour. Technol. 101, 7556-7562. doi: 10.1016/j.biortech.2010.04.027

Jacob, S., Chintagunta, A. D., and Banerjee, R. (2016). Selective digestion of industrial potato wastes for efficient biomethanation: a sustainable solution for safe environmental disposal. Int. J. Environ. Sci. Technol. 13, 2363-2374. doi: 10.1007/s13762-016-1051-y

Jena, P. C., Raheman, H., Kumar, G. V. P., and Machavaram, R. (2010). Biodiesel production from mixture of mahua and simarouba oils with high free fatty acids. Biomass Bioenergy 34, 1108-1116. doi: 10.1016/j.biombioe.2010.02.019

Jiao, X., Zhang, Y., Liu, X., Zhang, Q., Zhang, S., and Zhao, Z. K. (2019). Developing a CRISPR/Cas9 system for genome editing in the basidiomycetous yeast Rhodosporidium toruloides. Biotechnol. J. 14:1900036. doi: 10.1002/biot. 201900036

Jin, M., Slininger, P. J., Dien, B. S., Waghmode, S., Moser, B. R., Orjuela, A., et al. (2015). Microbial lipid-based lignocellulosic biorefinery: feasibility and challenges. Trends Biotechnol. 33, 43-54. doi: 10.1016/j.tibtech.2014.11.005

Jönsson, L. J., and Martín, C. (2016). Pretreatment of lignocellulose: formation of inhibitory by-products and strategies for minimizing their effects. Bioresour. Technol. 199, 103-112. doi: 10.1016/j.biortech.2015.10.009
Kakkad, H., Khot, M., Zinjarde, S., and Kumar, A. R. (2015). Biodiesel production by direct in situ transesterification of an oleaginous tropical mangrove fungus grown on untreated agro-residues and evaluation of its fuel properties. Bioenergy Res. 8, 1788-1799. doi: 10.1007/s12155-015-9626-x

Kalscheuer, R., Stolting, T. T., and Steinbuchel, A. (2006). Microdiesel: Escherichia coli engineered for fuel production. Microbiology 152(Pt 9), 2529-2536. doi: 10.1099/mic.0.29028-0

Kanakdande, A. P., Khobragade, C. N., and Mane, R. S. (2020). Utilization of pomegranate waste-peel as a novel substrate for biodiesel production by Bacillus cereus (MF908505). Sustain. Energy Fuels 4, 1199-1207. doi: 10.1039/ C9SE00584F

Keegan, D., Kretschmer, B., Elbersen, B., and Calliope, P. (2013). Cascading use: a systematic approach to biomass beyond the energy sector. Biofuels Bioprod. Biorefin. 7, 193-206. doi: 10.1002/bbb

Khot, M., and Ghosh, D. (2017). Lipids of Rhodotorula mucilaginosa IIPL32 with biodiesel potential: oil yield, fatty acid profile, fuel properties. J. Basic Microbiol. 57, 345-352. doi: 10.1002/jobm.201600618

Khot, M., Gouri, R., Debashish, G., Alarcón-vivero, M., Contreras, D., and Ravikumar, A. (2020). Lipid recovery from oleaginous yeasts: perspectives and challenges for industrial applications. Fuel 259:116292. doi: 10.1016/j.fuel.2019. 116292

Knothe, G. (2006). Analyzing biodiesel: standards and other methods. J. Am. Oil Chem. Soc. 83, 823-833. doi: 10.1007/s11746-006-5033-y

Koh, C. M. J., Liu, Y., Du, M., and Ji, L. (2014). Molecular characterization of KU70 and KU80 homologues and exploitation of a KU70-deficient mutant for improving gene deletion frequency in Rhodosporidium toruloides. BMC Microbiol. 14:50. doi: 10.1186/1471-2180-14-50

Kosa, G., Zimmermann, B., Kohler, A., Ekeberg, D., Afseth, N. K., Mounier, J., et al. (2018). High-throughput screening of Mucoromycota fungi for production of low-and high-value lipids. Biotechnol. Biofuels 11, 1-17. doi: 10.1186/s13068018-1070-7

Kosa, M., and Ragauskas, A. J. (2012). Bioconversion of lignin model compounds with oleaginous Rhodococci. Appl. Microbiol. Biotechnol. 93, 891-900. doi: 10. 1007/s00253-011-3743-z

Kucharska, K., Łukajtis, R., Słupek, E., Cieśliński, H., Rybarczyk, P., and Kamiński, M. (2018). Hydrogen production from energy poplar preceded by MEA pre-treatment and enzymatic hydrolysis. Molecules 23, 1-21. doi: 10.3390/ molecules23113029

Kucharska, K., Słupek, E., Cieśliński, H., and Kamiński, M. (2020). Advantageous conditions of saccharification of lignocellulosic biomass for biofuels generation via fermentation processes. Chem. Zvesti. 74, 1199-1209. doi: 10.1007/s11696019-00960-1

Kuhad, R. C., and Singh, A. (1993). Lignocellulose biotechnology: current and future prospects. Crit. Rev. Biotechnol. 13, 151-172. doi: 10.3109/ 07388559309040630

Kumar, B., Bhardwaj, N., Agrawal, K., Chaturvedi, V., and Verma, P. (2020a). Current perspective on pretreatment technologies using lignocellulosic biomass: an emerging bio refinery concept. Fuel Process. Technol. 199:106244. doi: 10.1016/j.fuproc.2019.106244

Kumar, D., Singh, B., and Korstad, J. (2017a). Utilization of lignocellulosic biomass by oleaginous yeast and bacteria for production of biodiesel and renewable diesel. Renew. Sustain. Energy Rev. 73, 654-671. doi: 10.1016/j.rser.2017. 01.022

Kumar, K. K., Deeba, F., Sauraj, Negi, Y. S., and Gaur, N. A. (2020b). Harnessing pongamia shell hydrolysate for triacylglycerol agglomeration by novel oleaginous yeast Rhodotorula pacifica INDKK. Biotechnol. Biofuels. 13:175. doi: 10.1186/s13068-020-01814-9

Kumar, N. S., Geetha, R. S., Vasu, A. T., and Ramu, D. V. (2019). Performance assessment of biodiesel transesterified from Labeo rohita visceral oil using IC engine. Curr. Trends Biotechnol. Pharm. 13, 348-356.

Kumar, N. S., Sarbon, N. M., Rana, S. S., Chintagunta, A. D., Prathibha, S., Ingilala, S. K., et al. (2021). Extraction of bioactive compounds from Psidium guajava leaves and its utilization in preparation of jellies. AMB Expr. 11, 1-9. doi: 10.1186/s13568-021-01194-9

Kumar, P., Barrett, D. M., Delwiche, M. J., and Stroeve, P. (2009). Methods for pretreatment of lignocellulosic biomass for effcient hydrolysis and biofuel production. Ind. Eng. Chem. Res. 48, 3713-3729. doi: 10.1021/ie801 $542 \mathrm{~g}$ 
Kumar, S. P. J., and Banerjee, R. (2013). Optimization of lipid enriched biomass production from oleaginous fungus using response surface methodology. Indian J. Exp. Biol. 51, 979-983.

Kumar, S. P. J., and Banerjee, R. (2019). Enhanced lipid extraction from oleaginous yeast biomass using ultrasound assisted extraction: a greener and scalable process. Ultrason. Sonochem. 52, 25-32. doi: 10.1016/j.ultsonch.2018.08.003

Kumar, S. P. J., Avanthi, A., Chintagunta, A. D., Gupta, A., and Banerjee, R. (2020c). "Oleaginous lipid: a drive to synthesize and utilize as biodiesel," in Practices and Perspectives in Sustainable Bioenergy. Green Energy and Technology, eds M. Mitra and A. Nagchaudhuri (New Delhi: Springer). doi: 10.1007/978-81-3223965-9_6

Kumar, S. P. J., Garlapati, V. K., Dash, A., Scholz, P., and Banerjee, R. (2017b). Sustainable green solvents and techniques for lipid extraction from microalgae: a review. Algal Res. 21, 138-147. doi: 10.1016/j.algal.2016.11.014

Kumar, S. P. J., Gujjala, L. K. S., Dash, A., Talukdar, B., and Banerjee, R. (2017c). "Biodiesel production from lignocellulosic biomass using oleaginous microbes," in Lignocellulosic Biomass Production and Industrial Applications, eds A. Kuila and V. Sharma (Hoboken, NJ: Wiley), 65-92. doi: $10.1002 / 9781119323686 . c h 4$

Kumar, S. P. J., Kumar, N. S., and Chintagunta, A. D. (2020d). Bioethanol production from cereal crops and lignocelluloses rich agro-residues: prospects and challenges. SN Appl. Sci. 2:1673. doi: 10.1007/s42452-020-03471-x

Kumar, V. G., Chandel, A. K., Kumar, S. P. J., Sharma, S., Sevda, S., Ingle, A. P., et al. (2020e). Circular economy aspects of lignin: towards a lignocellulose biorefinery. Renew. Sustain. Energy Rev. 130:109977. doi: 10.1016/j.rser.2020.1 09977

Kumari, A., Mahapatra, P., Garlapati, V. K., and Banerjee, R. (2009). Enzymatic transesterification of jatropha oil. Biotechnol. Biofuels 2:1. doi: 10.1186/17546834-2-1

Kurosawa, K., and Sinskey, A. J. (2013). Engineering xylose metabolism in triacylglycerol producing Rhodococcusopacus for lignocellulosic fuel production. Biotechnol. Biofuels. 6, 134-147. doi: 10.1186/1754-6834-6-134

Lam, M. K., and Lee, K. T. (2012). Renewable and sustainable bioenergies production from palm oil mill effluent (POME): win-win strategies toward better environmental protection. Biotechnol. Adv. 29, 124-141. doi: 10.1016/j. biotechadv.2010.10.001

Leesing, R., and Karraphan, P. (2011). Kinetic growth of the isolated oleaginous yeast for microbial lipid production. Afr. J. Biotechnol. 10, 13867-13877. doi: 10.5897/AJB10.2162

Levering, J., Broddrick, J., and Zengler, K. (2015). Engineering of oleaginous organisms for lipid production. Curr. Opin. Biotechnol. 36, 32-39. doi: 10.1016/ j.copbio.2015.08.001

Li, C., Wang, L., Chen, Z., Li, Y., Wang, R., Luo, X., et al. (2015). Ozonolysis pretreatment of maize stover: the interactive effect of sample particle size and moisture on ozonolysis process. Bioresour. Technol. 183, 240-247. doi: 10.1016/ j.biortech.2015.01.042

Li, P., Miao, X., Li, R., and Zhong, J. (2001). In situ biodiesel production from fastgrowing and high oil content Chlorella pyrenoidosa in rice straw hydrolysate. J. Biomed. Biotechnol. 1-8. doi: 10.1155/2011/141207

Liang, Y., Sarkany, N., Cui, Y., Yesuf, J., Trushenski, J., and Blackburn, J. W. (2010). Use of sweet sorghum juice for lipid production by Schizochytriumlimacinum SR21. Bioresour. Technol. 101, 3626-3627. doi: 10. 1016/j.biortech.2009.12.087

Liang, Y., Tang, T., Siddaramu, T., Choudhary, R., and Umagiliyage, A. L. (2012). Lipid production from sweet sorghum bagasse through yeast fermentation. Renew. Energy. 40, 130-136.

Liu, L., Chen, J., Lim, P.-E., and Wei, D. (2018). Enhanced single cell oil production by mixed culture of Chlorella pyrenoidosa and Rhodotorula glutinis using cassava bagasse hydrolysate as carbon source. Bioresour. Technol. 255, 140-148. doi: 10.1016/j.biortech.2018.01.114

Liu, L., Song, J., Li, Y., Li, P., and Wang, H. (2019). Robust and cost-saving static solid cultivation method for lipid production using the chlamydospores of Phanerochaete chrysosporium. Biotechnol. Biofuels 12:123. doi: 10.1186/s13068019-1464-1

Liu, W., Wang, Y., Yu, Z., Yu, Z., and Bao, J. (2012). Simultaneous saccharification and microbial lipid fermentation of corn stover by oleaginous yeast Trichosporoncutaneum. Bioresour. Technol. 118, 13-18. doi: 10.1016/j.biortech. 2012.05.038
Liu, Y., Wang, Y., Liu, H., and Zhang, J. A. (2015). Enhanced lipid production with undetoxified corncob hydrolysate by Rhodotorula glutinis using a high cell density culture strategy. Bioresour. Technol. 180, 32-39. doi: 10.1016/j.biortech. 2014.12.093

Llamas, M., Dourou, M., González-Fernández, C., Aggelis, G., and Tomás-Pejó, E. (2020). Screening of oleaginous yeasts for lipid production using volatile fatty acids as substrate. Biomass Bioenergy 138:105553. doi: 10.1016/j.biombioe.2020. 105553

Lopes, A. M., Ferreira Filho, E. X., and Moreira, L. R. S. (2018). An update on enzymatic cocktails for lignocellulose breakdown. J. Appl. Microbiol. 125, 632-645. doi: 10.1111/jam.13923

Lu, X., Vora, H., and Khosla, C. (2008). Overproduction of free fatty acids in E. coli: implications for biodiesel production. Metab. Eng. 10, 333-339. doi: 10.1016/j.ymben.2008.08.006

Lu, Y., Zhai, Y., Liu, M., and Wu, Q. (2010). Biodiesel production from algal oil using cassava (Manihotesculenta Crantz) as feedstock. J. Appl. Phycol. 22, 573-578. doi: 10.1007/s10811-009-9496-8

Luis, A., Garay, L. A., Sitepu, I. R., Cajka, T., Chandra, I., Shi, S., et al. (2016). Eighteen new oleaginous yeast species. J. Ind. Microbiol. Biotechnol. 43, 887900. doi: 10.1007/s10295-016-1765-3

Lv, Y., Gu, Y., Xu, J., Zhou, J., and Xu, P. (2020). Coupling metabolic addiction with negative autoregulation to improve strain stability and pathway yield. Metabol. Eng. 61, 79-88. doi: 10.1016/j.ymben.2020. 05.005

Ma, B., Li, Q., Niwa, T., Oura, T., Du, W., Liu, D., et al. (2008). Improvement of lipid accumulation in an oleaginous yeast. J. Biotechnol. 136, S415-S415. doi: 10.1002/elsc.201800203

Ma, Y. L. (2006). Microbial oils and its research advance. Chin. J. Bioprocess. Eng. 4, 7-11. doi: 10.1590/S1516-89132012000100004

Maddi, B., Viamajala, S., and Varanasi, S. (2018). Pyrolytic fractionation: a promising thermochemical technique for processing oleaginous (algal) biomass. ACS Sustain. Chem. Eng. 6, 237-247. doi: 10.1021/acssuschemeng. $7 \mathrm{~b} 02309$

Maurya, D. P., Singla, A., and Negi, S. (2015). An overview of key pretreatment processes for biological conversion of lignocellulosic biomass to bioethanol. 3 Biotech 5, 597-609. doi: 10.1007/s13205-015-0279-4

Meng, X., Yang, J., Xu, X., Zhang, L., Nie, Q., and Xian, M. (2009). Biodiesel production from oleaginous microorganisms. Renew. Energy 34, 1-5. doi: 10. 1016/j.renene.2008.04.014

Miao, Z., Tian, X., Liang, W., He, Y., and Wang, G. (2020). Bioconversion of corncob hydrolysate into microbial lipid by an oleaginous yeast Rhodotorula taiwanensis AM2352 for biodiesel production. Renew. Energy 161, 91-97. doi: 10.1016/j.renene.2020.07.007

Mosier, N. S., Wyman, C., Dale, B., Elander, R., Lee, Y. Y., Holtzapple, M., et al. (2005). Features of promising technologies for pretreatment of lignocellulosic biomass. Bioresour. Technol. 96, 673-686. doi: 10.1016/j. biortech.2004.06.025

Mu, J., Li, S., Chen, D., Xu, H., Han, F., Feng, B., et al. (2015). Enhanced biomass and oil production from sugarcane bagasse hydrolysate (SBH) by heterotrophic oleaginous microalga Chlorella protothecoides. Bioresour. Technol. 185, 99-105. doi: 10.1016/j.biortech.2015.02.082

Mühlroth, A., Winge, P., El Assimi, A., Jouhet, J., Maréchal, E., Hohmann-Marriott, M. F., et al. (2017). Mechanisms of phosphorus acquisition and lipid class remodeling under P limitation in a marine microalga. Plant Physiol. 175, 1543-1559. doi: 10.1104/pp.17.00621

Nair, A. S., Al-Bahry, S., Gathergood, N., Tripathi, B. N., and Sivakumar, N. (2020). Production of microbial lipids from optimized waste office paper hydrolysate, lipid profiling and prediction of biodiesel properties. Renew. Energy 148, 124134. doi: $10.1016 /$ j.renene.2019.12.008

Nathan, R. M., Kelley, P., Klaski, R., Bosco, A., Moore, B., and Traviss, N. (2019). Characterization and comparison of oxidative potential of real-world biodiesel and petroleum diesel particulate matter emitted from a non-road heavy duty diesel engine. Sci. Total Environ. 655, 908-914. doi: 10.1016/j.scitotenv.2018.1 1.292

Nguyena, H. C., Sub, C.-H., Yub, Y.-K., and Huong, D. T. M. (2018). Sugarcane bagasse as a novel carbon source for heterotrophic cultivation of oleaginous microalga Schizochytrium sp. Ind. Crops Prod. 121, 99-105. doi: 10.1016/j. indcrop.2018.05.005 
Nogué, V. S., Black, B. A., Kruger, J. S., Singer, C. A., Ramirez, K. J., Reed, M. L., et al. (2018). Integrated diesel production from lignocellulosic sugars via oleaginous yeast. Green Chem. 20, 4349-4365. doi: 10.1039/C8GC01905C

Nora, L. C., Wehrs, M., Kim, J., Cheng, J.-F., Tarver, A., Simmons, B. A., et al. (2019). A toolset of constitutive promoters for metabolic engineering of Rhodosporidium toruloides. Microb. Cell Fact. 18:117. doi: 10.1186/s12934-0191167-0

Olofsson, K., Bertilsson, M., and Lidén, G. (2008). A short review on SSFan interesting process option for ethanol production from lignocellulosic feedstocks. Biotechnol. Biofuels 1:7. doi: 10.1186/1754-6834-1-7

Ong, H. R., Khan, M. R., Chowdhury, M. N. K., Yousuf, A., and Cheng, C. K. (2014). Synthesis and characterization of $\mathrm{CuO} / \mathrm{C}$ catalyst for the esterification of free fatty acid in rubber seed oil. Fuel 120, 195-201. doi: 10.1016/j.fuel.2013. 12.015

Otoupal, P. B., Ito, M., Arkin, A. P., Magnuson, J. K., Gladden, J. M., and Skerker, J. M. (2019). Multiplexed CRISPR-Cas9-based genome editing of Rhodosporidium toruloides. Msphere 4:19. doi: 10.1128/mSphere.00099-19

Papanikolaou, S., and Aggelis, G. (2011). Lipids of oleaginous yeasts. Part I: biochemistry of single cell oil production. Eur. J. Lipid Sci. Technol. 113, 1031-1051. doi: 10.1002/ejlt.201100014

Papanikolaou, S., and Aggelis, G. (2019). Sources of microbial oils with emphasis to Mortierella (Umbelopsis) isabellina fungus. World J. Microbiol. Biotechnol. 35:63. doi: 10.1007/s11274-019-2631-z

Park, Y.-K., Nicaud, J.-M., and Ledesma-Amaro, R. (2018). The engineering potential of Rhodosporidium toruloides as a workhorse for biotechnological applications. Trends Biotechnol. 36, 304-317. doi: 10.1016/j.tibtech.2017.10.013

Patel, A., Arora, N., Mehtani, J., Pruthi, V., and Pruthi, P. A. (2017). Assessment of fuel properties on the basis of fatty acid profiles of oleaginous yeast for potential biodiesel production. Renew. Sustain. Energy Rev. 77, 604-616. doi: 10.1016/j.rser.2017.04.016

Patel, A., Arora, N., Sartaj, K. M., Pruthi, V., and Pruthi, P. A. (2016). Sustainable biodiesel production from oleaginous yeasts utilizing hydrolysates of various non-edible lignocellulosic biomasses. Renew. Sustain. Energy Rev. 62, 836-855. doi: 10.1016/j.rser.2016.05.014

Patel, A., Matsakas, L., Rova, U., and Christakopoulos, P. (2018). Heterotrophic cultivation of Auxenochlorella protothecoides using forest biomass as a feedstock for sustainable biodiesel production. Biotechnol. Biofuels 11:169. doi: 10.1186/ s13068-018-1173-1

Patel, A., Pruthi, V., Singh, R. P., and Pruthi, P. A. (2015). Synergistic effect of fermentable and non-fermentable carbon sources enhances TAG accumulation in oleaginous yeast Rhodosporidium kratochvilovae HIMPA1. Bioresour. Technol. 188, 136-144. doi: 10.1016/j.biortech.2015.02.062

Peng, X. W., and Chen, H. Z. (2008). Single cell oil production in solid-state fermentation by Microsphaeropsis sp. from steam-exploded wheat straw mixed with wheat bran. Bioresour. Technol. 99, 3885-3889. doi: 10.1016/j.biortech. 2007.08.015

Pérez, J., Muñoz-Dorado, J., de la Rubia, T., and Martínez, J. (2002). Biodegradation and biological treatments of cellulose, hemicellulose and lignin: an overview. Int. Microbiol. 5, 53-63. doi: 10.1007/s10123-002-0062-3

Pinzi, S., Leiva-Candia, D., López-García, I., Redel-Macías, M. D., and Dorado, M. P. (2013). Latest trends in feedstocks for biodiesel production. Biofuels Bioprod. Biorefin. 8, 126-143. doi: 10.1002/bbb.1435

Pleissner, D., Lam, W. C., Sun, Z., and Lin, C. S. K. (2013). Food waste as nutrient source in heterotrophic microalgae cultivation. Bioresour. Technol. 137, 139-146. doi: 10.1016/j.biortech.2013.03.088

Poontawee, R., Yongmanitchai, W., and Limtong, S. (2017). Efficient oleaginous yeasts for lipid production from lignocellulosic sugars and effects of lignocellulose degradation compounds on growth and lipid production. Process Biochem. 53, 44-60. doi: 10.1016/j.procbio.2016.11.013

Qiao, W., Tao, J., Luo, Y., Tang, T., Miao, J., and Yang, Q. (2018). Microbial oil production from solid-state fermentation by a newly isolated oleaginous fungus, Mucor circinelloides Q531 from mulberry branches. R. Soc. Open Sci. 5:180551. doi: 10.1098/rsos.180551

Quarterman, J. C., Slininger, P. J., Hector, R. E., and Dien, B. S. (2018). Engineering Candida phangngensis-an oleaginous yeast from the Yarrowia clade-for enhanced detoxification of lignocellulose-derived inhibitors and lipid overproduction. FEMS Yeast Res. 18:foy102. doi: $10.1093 /$ femsyr/foy102
Ramírez-Verduzco, L. F., Rodríguez-Rodríguez, J. E., and del Rayo Jaramillo-Jacob, A. (2012). Predicting cetane number, kinematic viscosity, density and higher heating value of biodiesel from its fatty acid methyl ester composition. Fuel 91, 102-111. doi: 10.1016/j.fuel.2011.06.070

Ratledge, C. (1988). "Biochemistry, stoichiometry, substrates and economics," in Single Cell Oil, ed. R. S. Moreton (Harlow: Longman Scientific and Technical), 33-70.

Ratledge, C. (2004). Fatty acid biosynthesis in microorganisms being used for single cell oil production. Biochimie 86, 807-815. doi: 10.1016/j.biochi.2004.09. 017

Ratledge, C., and Wynn, J. P. (2002). The biochemistry and molecular biology of lipid accumulation in oleaginous microorganisms. Adv. Appl. Microbiol. 51, 1-52. doi: 10.1016/s0065-2164(02)51000-5

Rossi, M., Amaretti, A., and Raimondi, S. (2011). "Getting lipids for biodiesel production from oleaginous fungi," in Biodiesel - Feedstocks and Processing Technologies, eds M. Stoytcheva and G. Montero (Rijeka: InTech publishers), 71-92.

Ruan, Z., Zanotti, M., Wang, X., Ducey, C., and Liu, Y. (2012). Evaluation of lipid accumulation from lignocellulosic sugars by Mortierella isabellina for biodiesel production. Bioresour. Technol. 110, 198-205. doi: 10.1016/j.biortech.2012.0 1.053

Saini, J. K., Saini, R., and Tewari, L. (2015). Lignocellulosic agriculture wastes as biomass feedstocks for second-generation bioethanol production: concepts and recent developments. 3 Biotech 5, 337-353. doi: 10.1007/s13205014-0246-5

Sajjadi, B., Raman, A. A. A., and Arandiyan, H. (2016). A comprehensive review on properties of edible and non-edible vegetable oil-based biodiesel: composition, specifications and prediction models. Renew. Sustain. Energy Rev. 63, 62-92. doi: 10.1016/j.rser.2016.05.035

Santek, M. I., Beluhan, S., and Santek, B. (2018). "Production of microbial lipids from lignocellulosic biomass," in Advances in Biofuels Bioenergy, eds M. Nageswara-Rao and J. R. Soneji (London: IntechOpen), 137-164. doi: 10.5772/ intechopen.74013

Sathiyamoorthi, E., Kumar, P., and Kim, B. S. (2019). Lipid production by Cryptococcus albidus using biowastes hydrolysed by indigenous microbes. Bioprocess Biosyst. Eng. 42, 687-696. doi: 10.1007/s00449-019-02073-1

Schörken, U., and Kempers, P. (2009). Lipid biotechnology: industrially relevant production processes. Eur. J. Lipid Sci. Technol. 111, 627-645. doi: 10.1002/ejlt. 200900057

Schultz, J. C., Cao, M., and Zhao, H. (2019). Development of a CRISPR/Cas9 system for high efficiency multiplexed gene deletion in Rhodosporidium toruloides. Biotechnol. Bioeng. 116, 2103-2109. doi: 10.1002/bit. 27001

Shaheena, S., Chintagunta, A. D., Dirisala, V. R., and Kumar, N. S. (2019). Extraction of bioactive compounds from Psidium guajava and their application in dentistry. AMB Expr. 9, 1-9. doi: 10.1186/s13568-019-0935-x

Sharma, Y. C., and Singh, B. (2010). An ideal feedstock, kusum (Schleicher atriguga) for preparation of biodiesel: optimization of parameters. Fuel 89, 1470-1474. doi: 10.1016/j.fuel.2009.10.013

Shi, S., and Zhao, H. (2017). Metabolic engineering of oleaginous yeasts for production of fuels and chemicals. Front. Microbiol. 8:2185. doi: 10.3389/fmicb. 2017.02185

Shih, S. C., Goyal, G., Kim, P. W., Koutsoubelis, N., Keasling, J. D., Adams, P. D., et al. (2015). A versatile microfluidic device for automating synthetic biology. ACS Synth. Biol. 4, 1151-1164. doi: 10.1021/acssynbio.5b00062

Shimada, Y., Watanabe, Y., Sugihara, A., and Tominaga, Y. (2002). Enzymatic alcoholysis for biodiesel fuel production and application of the reaction to oil processing. J. Mol. Catal. B Enzym. 17, 133-142. doi: 10.1016/S1381-1177(02) 00020-6

Singh, D., Sharma, D., Soni, S. L., Sharma, S., Sharma, P. K., and Jhalani, A. (2020). A review on feedstocks, production processes, and yield for different generations of biodiesel. Fuel 262:116553. doi: 10.1016/j.fuel.2019.1 16553

Singh, S., Simmons, B. A., and Vogel, K. P. (2009). Visualization of biomass solubilization and cellulose regeneration during ionic liquid pretreatment of switchgrass. Biotechnol. Bioeng. 104, 68-75. doi: 10.1002/bit.22386

Siwina, S., and Leesing, R. (2021). Bioconversion of durian (Durio zibethinus Murr.) peel hydrolysate into biodiesel by newly isolated oleaginous yeast 
Rhodotorula mucilaginosa KKUSY14. Renew. Energy 163, 237-245. doi: 10. 1016/j.renene.2020.08.138

Somerville, C., Youngs, H., Taylor, C., Davis, S., and Long, S. (2010). Feedstocks for lignocellulosic biofuels. Science 329, 790-792. doi: 10.1126/science.1189268

Spagnuolo, M., Yaguchi, A., and Blenner, M. (2019). Oleaginous yeast for biofuel and oleochemical production. Curr. Opin. Biotechnol. 2019, 73-81. doi: 10. 1016/j.copbio.2019.02.011

Sreeharsha, R. V., and Mohan, S. V. (2020). Obscure yet promising oleaginous yeasts for fuel and chemical production. Trends Biotechnol. 38, 873-887. doi: 10.1016/j.tibtech.2020.02.004

Stamenković, O. S., Veličković, A. V., and Veljković, V. B. (2011). The production of biodiesel from vegetable oils by ethanolysis: current state and perspectives. Fuel 90, 3141-3155. doi: 10.1016/j.fuel.2011.06.049

Stansell, G. R., Gray, V. M., and Sym, S. D. (2012). Microalgal fatty acid composition: implications for biodiesel quality. J. Appl. Phycol. 24, 791-801. doi: 10.1007/s10811-011-9696-x

Subramanian, R., Dufreche, S., Zappi, M., and Bajpai, R. (2010). Microbial lipids from renewable resources: production and characterization. J. Ind. Microbiol. Biotechnol. 37, 1271-1287. doi: 10.1007/s10295-010-0884-5

Supple, B., Holward-Hildige, R., Gonzalez-Gomez, E., and Leahy, J. J. (2002). The effect of steam treating waste cooking oil on the yield of methyl ester. J. Am. Oil Chem. Soc. 79, 175-178. doi: 10.1007/s11746-002-0454-1

Sykes, R. W., Gjersing, E. L., Foutz, K., Rottmann, W. H., Kuhn, S. A., Foster, C. E., et al. (2015). Down-regulation of p-coumaroyl quinate/shikimate 3'-hydroxylase $\left(\mathrm{C}^{\prime} \mathrm{H}\right)$ and cinnamate 4-hydroxylase $(\mathrm{C} 4 \mathrm{H})$ genes in the lignin biosynthetic pathway of Eucalyptus urophyllax E. grandis leads to improved sugar release. Biotechnol. Biofuels 8:128. doi: 10.1186/s13068-0150316-x

Tai, M., and Stephanopoulos, G. (2013). Engineering the push and pull of lipid biosynthesis in oleaginous yeast Yarrowia lipolytica for biofuel production. Metab. Eng. 15, 1-9. doi: 10.1016/j.ymben.2012.08.007

Talavari, R., Hosseini, S., and Moradi, G. R. (2020). Low-cost biodiesel production using waste oil and catalyst. Waste Manag. Res. 39, 250-259. doi: 10.1177/ $0734242 X 20935174$

Tan, H., Yang, R., Sun, W., and Wang, S. (2010). Peroxide- acetic acid pretreatment to remove bagasse lignin prior to enzymatic hydrolysis. Ind. Eng. Chem. 49, 1473-1479. doi: 10.1021/ie901529q

Tanimura, A., Takashima, M., Sugita, T., Endoh, R., Ohkuma, M., Kishino, S., et al. (2016). Lipid production through simultaneous utilization of glucose, xylose, and l-arabinose by Pseudozyma hubeiensis: a comparative screening study. AMB Expr. 2016:58. doi: 10.1186/s13568-016-02 36-6

Tsigie, Y. A., Huynh, L. H., Ahmed, I. N., and Ju, Y.-H. (2012). Maximizing biodiesel production from Yarrowialipolytica Polg biomass using subcritical water pretreatment. Bioresour. Technol. 111, 201-207. doi: 10.1016/j.biortech. 2012.02.052

Tsukahara, K., and Sawayama, S. (2005). Liquid fuel production using microalgae. J. Jpn. Petrol Inst. 48, 251-259. doi: 10.1627/jpi.48.251

Uthandi, S., Ashok Kumar, K., Srinivasan, N., Thangavelu, K., Munira, I. K., Zhanc, X., et al. (2021). Microbial biodiesel production from lignocellulosic biomass: new insights and future challenges. Crit. Rev. Environ. Sci. Technol. 12, 1-30. doi: 10.1080/10643389.2021.1877045

Valdés, G., Mendonça, R. T., and Aggelis, G. (2020). Lignocellulosic biomass as a substrate for oleaginous microorganisms: a review. Appl. Sci. 10:7698. doi: 10.3390/app10217698

Van Acker, R., Leplé, J.-C., Aerts, D., Storme, V., Goeminne, G., Ivens, B., et al. (2014). Improved saccharification and ethanol yield from field-grown transgenic poplar deficient in cinnamoyl-CoA reductase. Proc. Natl. Acad. Sci. U.S.A. 111, 845-850. doi: 10.1073/pnas.1321673111

Voss, I., and Steinbuchel, A. (2001). High cell density cultivation of Rhodococcusopacus for lipid production at a pilot-plant scale. Appl. Microbiol. Biot. 55, 547-555. doi: 10.1007/s002530000576

Wang, J. P., Matthews, M. L., Williams, C. M., Shi, R., Yang, C., Tunlaya-Anukit, S., et al. (2018). Improving wood properties for wood utilization through multiomics integration in lignin biosynthesis. Nat. Commun. 9:1579. doi: 10.1038/ s41467-018-03863-Z

Wang, J., , Q., Zhang, H., and Bao, J. (2016). Inhibitor degradation and lipid accumulation potentials of oleaginous yeas Gao $t$ Trichosporon cutaneum using lignocellulose feedstock. Bioresour. Technol. 218, 892-901. doi: 10.1016/j. biortech.2016.06.130

Wang, Q., Guo, F.-J., Rong, Y.-J., and Chi, Z.-M. (2012). Lipid production from hydrolysate of cassava starch by Rhodosporidiumtoruloides 21167 for biodiesel making. Renew. Energy. 46, 164-168. doi: 10.1016/j.renene.2012.03.002

Wang, Q., Sen, B., Liu, X., He, Y., Xie, Y., and Wang, G. (2018). Enhanced saturated fatty acids accumulation in cultures of newly-isolated strains of Schizochytrium sp. and Thraustochytriidae sp. for large-scale biodiesel production. Sci. Total Environ. 631, 994-1004. doi: 10.1016/j.scitotenv.2018.0 3.078

Wang, R., Hanna, M. A., Zhou, W. W., Bhadury, P. S., Chen, Q., and Song, B. A. (2011). Production and selected fuel properties of biodiesel from promising non-edible oils: Euphorbia lathyris L., Sapium sebiferum L. and Jatropha curcas L. Bioresour. Technol. 102, 1194-1199. doi: 10.1016/j.biortech.2010.0 9.066

Wang, R., Wang, J., Xu, R., Fang, Z., and Liu, A. (2014). Oil production by the oleaginous yeast Lipomyces starkeyi using diverse carbon sources. Bioresources 9, 7027-7040.

Wei, A., Zhang, X., Wei, D., Chen, G. U., Wu, Q., and Yang, S. T. (2009). Effects of cassava starch hydrolysate on cell growth and lipid accumulation of the heterotrophic microalgae Chlorella protothecoides. J. Ind. Microbiol. Biotechnol. 36, 1383-1389. doi: 10.1007/s10295-009-0624-x

Wei, Z., Zeng, G., Huang, F., Kosa, M., Huang, D., and Ragauskas, A. J. (2015). Bioconversion of oxygen-pretreated kraft lignin to microbial lipid with oleaginous Rhodococcus opacus DSM 1069. Green Chem. 17, 2784-2789. doi: 10.1039/C5GC00422E

Xavier, M. C. A., Coradini, A. L. V., Deckmann, A. C., and Franco, T. T. (2017). Lipid production from hemicellulose hydrolysate and acetic acid by Lipomycesstarkeyi and the ability of yeast to metabolize inhibitors. Biochem. Eng. J. 118, 11-19. doi: 10.1016/j.bej.2016.11.007

Xiong, X., and Chen, S. (2020). Expanding toolbox for genes expression of Yarrowia lipolytica to include novel inducible, repressible, and hybrid promoters. ACS Synth. Biol. 9, 2208-2213. doi: 10.1021/acssynbio.0c 00243

Xiong, X., Xia, Y., and Qiao, J. (2021). Physiology, application, and bioengineering of oleaginous microorganisms. Front. Microbiol. 12:650957. doi: 10.3389/fmicb. 2021.650957

Xu, H., Miao, X., and Wu, Q. (2006). High quality biodiesel production from a microalga Chlorella protothecoides by heterotrophic growth in fermenters. J. Biotechnol. 126, 499-507. doi: 10.1016/j.jbiotec.2006.05.002

Yaakob, Z., Mohammad, M., Alherbawi, M., Alam, Z., and Sopian, K. (2013). Overview of the production of biodiesel from waste cooking oil. Renew. Sustain. Energy Rev. 18, 184-193. doi: 10.1016/j.rser.2012.10.016

Yang, Z., Edwards, H., and Xu, P. (2020). CRISPR-Cas12a/Cpf1-assisted precise, efficient and multiplexed genome-editing in Yarrowia lipolytica. Metabol. Eng. Commun. 10:e00112. doi: 10.1016/j.mec.2019.e00112

Yeh, S. I., Huang, Y. C., Cheng, C. H., Cheng, C. M., and Yang, J. T. (2016). Development of a millimetrically scaled biodiesel transesterification device that relies on droplet-based co-axial fluidics. Sci. Rep. 6:29288.

Yen, H. W., and Chang, J. T. (2015). Growth of oleaginous Rhodotorula glutinis in an internal-loop airlift bioreactor by using lignocellulosic biomass hydrolysate as the carbon source. J. Biosci. Bioeng. 119, 580-584. doi: 10.1016/j.jbiosc.2014. 10.001

Yodsuwan, N., Sawayama, S., and Sirisansaneeyakul, S. (2017). Effect of nitrogen concentration on growth, lipid production and fatty acid pro fi les of the marine diatom Phaeodactylum tricornutum. Agric. Nat. Resour. 51, 190-197. doi: 10.1016/j.anres.2017.02.004

Younes, S., Bracharz, F., Awad, D., Qoura, F., Mehlmer, N., and Brueck, T. (2020). Microbial lipid production by oleaginous yeasts grown on Scenedesmus obtusiusculus microalgae biomass hydrolysate. Bioprocess Biosyst. Eng. 43, 1629-1638. doi: 10.1007/s00449-020-02354-0

Yousuf, A. (2012). Biodiesel from lignocellulosic biomass - prospects and challenges. Waste Manage. 32, 2061-2067. doi: 10.1016/j.wasman.2012. 03.008

Yu, X., Zheng, Y., Dorgan, K. M., and Chen, S. (2011). Oil production by oleaginous yeasts using the hydrolysate from pretreatment of wheat straw with dilute sulfuric acid. Bioresour. Technol. 102, 6134-6140. doi: 10.1016/j.biortech.2011. 02.081 
Yu, Y., Xu, Z., Chen, S., and Jin, M. (2020). Microbial lipid production from dilute acid and dilute alkali pretreated corn stover via Trichosporon dermatis. Bioresour. Technol. 295:122253. doi: 10.1016/j.biortech.2019.122253

Zhang, B., Li, W., Guo, Y., Zhang, Z., Shi, W., Cui, F., et al. (2020). Microalgal-bacterial consortia: from interspecies interactions to biotechnological applications. Renew. Sustain. Energy Rev. 118:109563. doi: 10.1016/j.rser.2019.109563

Zhang, Y., Dube, M. A., McLean, D. D., and Kates, M. (2003). Biodiesel production from waste cooking oil: 2. Economic assessment and sensitivity analysis. Bioresour. Technol. 90, 229-240. doi: 10.1016/S0960-8524(03)0 0150-0

Zhao, B. H., Chen, J., Yu, H. Q., Hu, Z. H., Yue, Z. B., and Li, J. (2017). Optimization of microwave pretreatment of lignocellulosic waste for enhancing methane production: hyacinth as an example. Front. Environ. Sci. Eng. 11:17. doi: 10. 1007/s11783-017-0965-Z

Zhao, X., Kong, X. L., Hua, Y. Y., Feng, B., and Zhao, Z. B. (2008). Medium optimization for lipid production through co-fermentation of glucose and xylose by the oleaginous yeast Lipomyces starkeyi. Eur. J. Lipid Sci. Technol. 110, 405-412. doi: 10.1002/ejlt.200700224

Zhao, X., Wu, S., Hu, C., Wang, Q., Hua, Y., and Zhao, Z. (2010). Lipid production from Jerusalem artichoke by Rhodosporidiumtoruloides Y4. J. Ind. Microbiol. Biotechnol. 37, 581-585. doi: 10.1007/s10295-010-0704-y

Zhou, C. H., Xia, X., Lin, X., Tong, S., and Beltramini, J. (2011). Catalytic conversion of lignocellulosic biomass to fine chemicals and fuels. Chem. Soc. Rev. 40, 5588-5617. doi: 10.1039/C1CS15 $124 \mathrm{~J}$

Zuccaro, G., Pirozzi, D., and Yousuf, A. (2020). "Lignocellulosic biomass to biodiesel," in Lignocellulosic Biomass to Liquid Biofuels, eds A. Yousuf, D. Pirozzi, and F. Sannino (Cambridge, MA: Academic Press), 127-167. doi: 10. 1016/B978-0-12-815936-1.00004-6

Conflict of Interest: The authors declare that the research was conducted in the absence of any commercial or financial relationships that could be construed as a potential conflict of interest.

Publisher's Note: All claims expressed in this article are solely those of the authors and do not necessarily represent those of their affiliated organizations, or those of the publisher, the editors and the reviewers. Any product that may be evaluated in this article, or claim that may be made by its manufacturer, is not guaranteed or endorsed by the publisher.

Copyright (c) 2021 Chintagunta, Zuccaro, Kumar, Kumar, Garlapati, Postemsky, Kumar, Chandel and Simal-Gandara. This is an open-access article distributed under the terms of the Creative Commons Attribution License (CC BY). The use, distribution or reproduction in other forums is permitted, provided the original author(s) and the copyright owner(s) are credited and that the original publication in this journal is cited, in accordance with accepted academic practice. No use, distribution or reproduction is permitted which does not comply with these terms. 